Article

\title{
Sulfur Isotope Ratios from VMS Deposits in the Penokean Volcanic Belt, Great Lakes Region, USA: Constraints on the Source of Sulfur in a Paleoproterozoic Intra-Arc Rift
}

\author{
Nicholas Moleski, Anthony Boxleiter and Joyashish Thakurta *(1) \\ Department of Geological and Environmental Sciences, Western Michigan University, 1903 W Michigan Ave \\ Kalamazoo, MI 49008, USA; nicholas.m.moleski@wmich.edu (N.M.); anthony.r.boxleiter@wmich.edu (A.B.) \\ * Correspondence: joyashish.thakurta@wmich.edu; Tel.: +1-(269)-387-3667
}

Received: 6 December 2018; Accepted: 20 December 2018; Published: 22 December 2018

\begin{abstract}
The Paleoproterozoic ( 1.8 Ga) Penokean Volcanic Belt (PVB) in the Great Lakes Region of North America hosts several polymetallic volcanogenic massive sulfide (VMS) deposits. These deposits were formed by back-arc extensional volcanism during the accretion of island-arc terranes along the southern margin of the Archean Superior Craton. This study reports $\delta^{34} S$ values obtained from sulfide minerals collected from eight VMS deposits in the PVB: Back Forty, Bend, Eisenbrey, Flambeau, Horseshoe, Lynne, Reef, and Schoolhouse. The average $\delta^{34} S$ values from most of these deposits lie within the mantle-range between -2 and $2 \%$, relative to Vienna Canyon Diablo Troilite (V-CDT). Average $\delta^{34} \mathrm{~S}$ values from Back Forty and Lynne deposits are slightly higher, at 2.5 and $2.4 \%$, respectively. No systematic variation in $\delta^{34} S$ was observed based on factors such as the kind of sulfide mineral, ore-texture, type of host rock, or the nature of host-rock alteration. The narrow observed range from the PVB offers a clear indication that sulfur in the mineralizing fluid, originated predominantly from a magmatic source. If there was a significant contribution of sulfur from seawater, the $\delta^{34} S$ of seawater sulfur must also have been close to the mantle range. Slightly higher values from Back Forty and Lynne indicate minor involvement of oxidized sulfur at shallow water levels, possibly derived from the continental margin.
\end{abstract}

Keywords: Penokean; VMS; Paleoproterozoic; sulfur; isotope; arc; rift; seawater

\section{Introduction}

Volcanogenic massive sulfide (VMS) deposits are well-known for economic mineralization of $\mathrm{Cu}, \mathrm{Zn}, \mathrm{Pb}, \mathrm{Au}$, and $\mathrm{Ag}$ [1-4]. VMS deposits are precipitated from metal-enriched fluids associated with hydrothermal convection at the seafloor. Ancient VMS deposits have been modelled to form predominantly in collisional environments along tectonic margins, during periods of extension and rifting $[1,3,5,6]$. Crustal thinning associated with diapiric up-rise of mantle-derived magma creates zones of high heat-flow and melting at shallow crustal levels. Convection currents of fluids driven by the near vertical thermal inhomogeneity under the oceanic crust and/or under collisional arc settings cause the metal-enriched brines to move to the surface or at shallow depths under the ocean-floor. The metallic sulfide minerals get precipitated as veneers in volcanically active areas in the ocean-floor, around fumarolic vents. Tectonic settings for VMS deposits include back-arc basins, island arcs, mid-ocean ridges, oceanic intraplate volcanoes, continental margin arcs, and continental rift/back arc basins $[3,7,8]$.

Sulfur isotope signatures are reliable geochemical tracers for the origin of mineral deposits through geological time [3,9-11]. Sulfur isotope ratios are particularly useful to investigate the 
sources of sulfur in VMS and other sulfide ore deposits primarily because the important reservoirs of sulfur such as magmatic sulfur, seawater sulfate, and diagenetic pyrite have distinct sulfur isotope signatures [9,12-14]. Furthermore, numerous studies on Archean and Proterozoic VMS deposits by authors such as Sharpe and Gemmell [15], Wagner [16], and Bailie et al. [17] have demonstrated that sulfur isotope ratios recorded in sulfide minerals within VMS deposits are not distorted by subsequent processes of structural deformation and regional metamorphism.

Sulfur isotope signatures have been used by several workers to model the geochemical characteristics of the mineralizing hydrothermal fluids of VMS deposits in the Archean and Proterozoic Eons. Apart from the studies mentioned above, there are more studies on sulfur isotope characteristics of VMS deposits in the Teutonic Bore Volcanic Complex, Western Australia [18], VMS deposits at Strelley, Pilbara Craton, Western Australia [19], and the VMS district of Tierra del Fuego, Argentina [20].

Sources of sulfur in the mineralizing fluids of VMS deposits have been widely debated by many authors, including: Lambert [21], Ohmoto and Rye [12], Ohmoto [13], Bowins and Crocket [22], Huston [9], Sharpe and Gemmell [15], Hannington et al. [7], Jamieson et al. [14], and Huston et al. [10]. Possible sources of sulfur include: (1) Upwelling magma from the mantle source, (2) dissolved seawater sulfate, and (3) sulfur precipitated as sulfides during diagenesis in reducing environments primarily in black shales. S-isotope ratios are powerful indicators of the sources of S. In this work, we have determined $\delta^{34} S$ ratios from sulfide mineral samples collected from eight VMS deposits in the Penokean Volcanic Belt (PVB) in the Great Lakes Region of North America (Figure 1). These deposits are: Back Forty, Bend, Eisenbrey, Flambeau, Horseshoe, Lynne, Reef, and Schoolhouse. We have included additional data from the Crandon deposit by Myers [23] and using these nine deposits we have developed a comprehensive database of $\delta^{34} S$ ratios along the $E-W$ extent of the PVB. We have used this database to model the origin of these deposits, to study S-isotope characteristics of an active Paleoproterozoic volcanic arc, and to constrain the S-isotope characteristics of seawater in Paleoproterozoic.

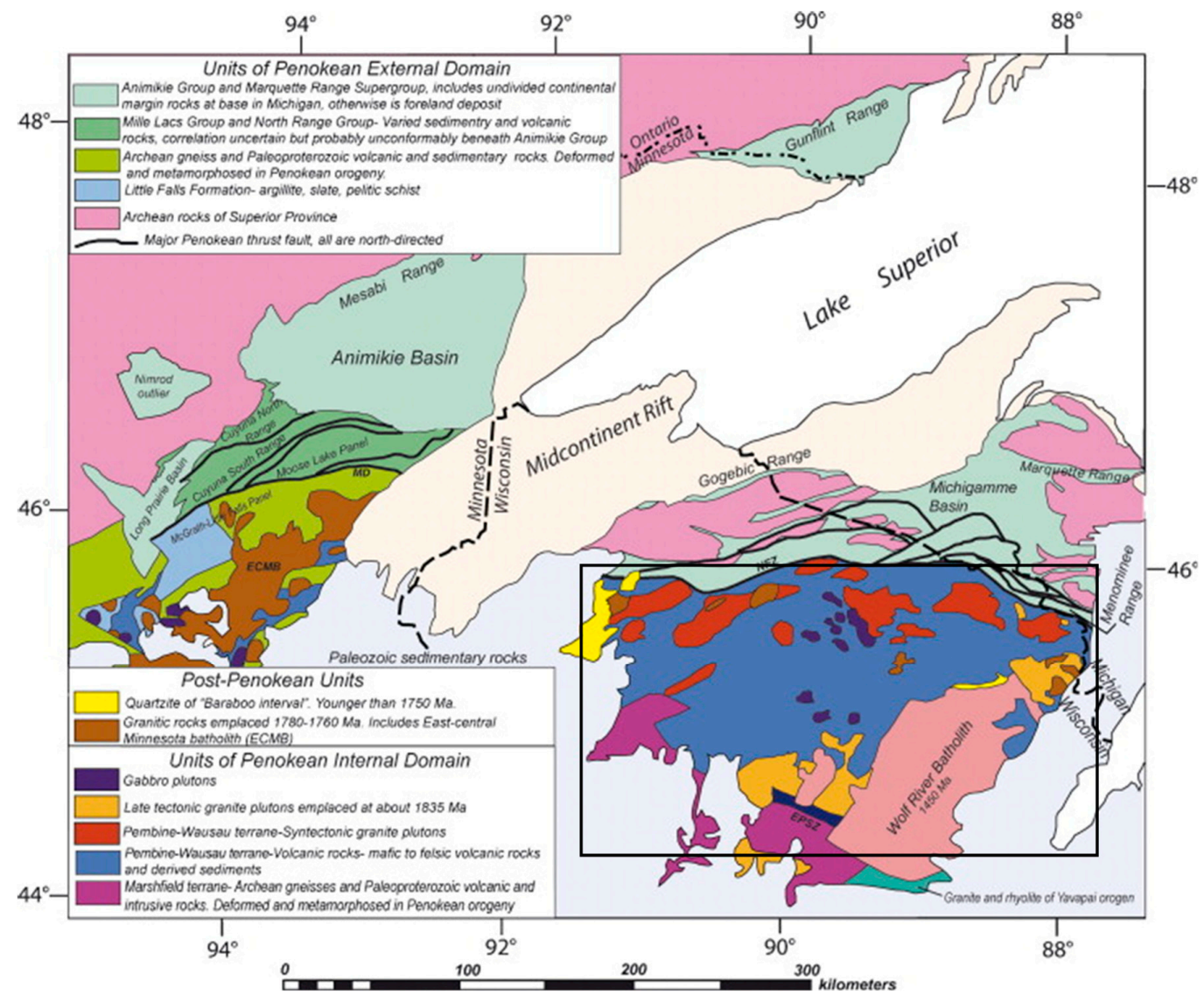


Figure 1. The location of the Penokean Volcanic Belt (within the box) in the wider region of Penokean Orogen in the Great Lakes Region [24]. The Penokean Orogen is divided into an external domain and an internal domain. The Penokean Volcanic Belt is part of the internal domain and it is primarily composed of mafic to felsic volcanic rocks of the Pembine-Wausau Terrane.

\subsection{Geological Setting}

The Penokean Volcanic Belt (PVB) located in the Great Lakes Region of North America (Figure 1) was formed by the Penokean Orogeny [24]. The Penokean Orogeny began at approximately $1.890 \mathrm{Ga}$ when a volcanic island arc, the Pembine-Wausau Terrane, approached the Archean Superior Craton during a period of south-directed subduction (Figure 2).

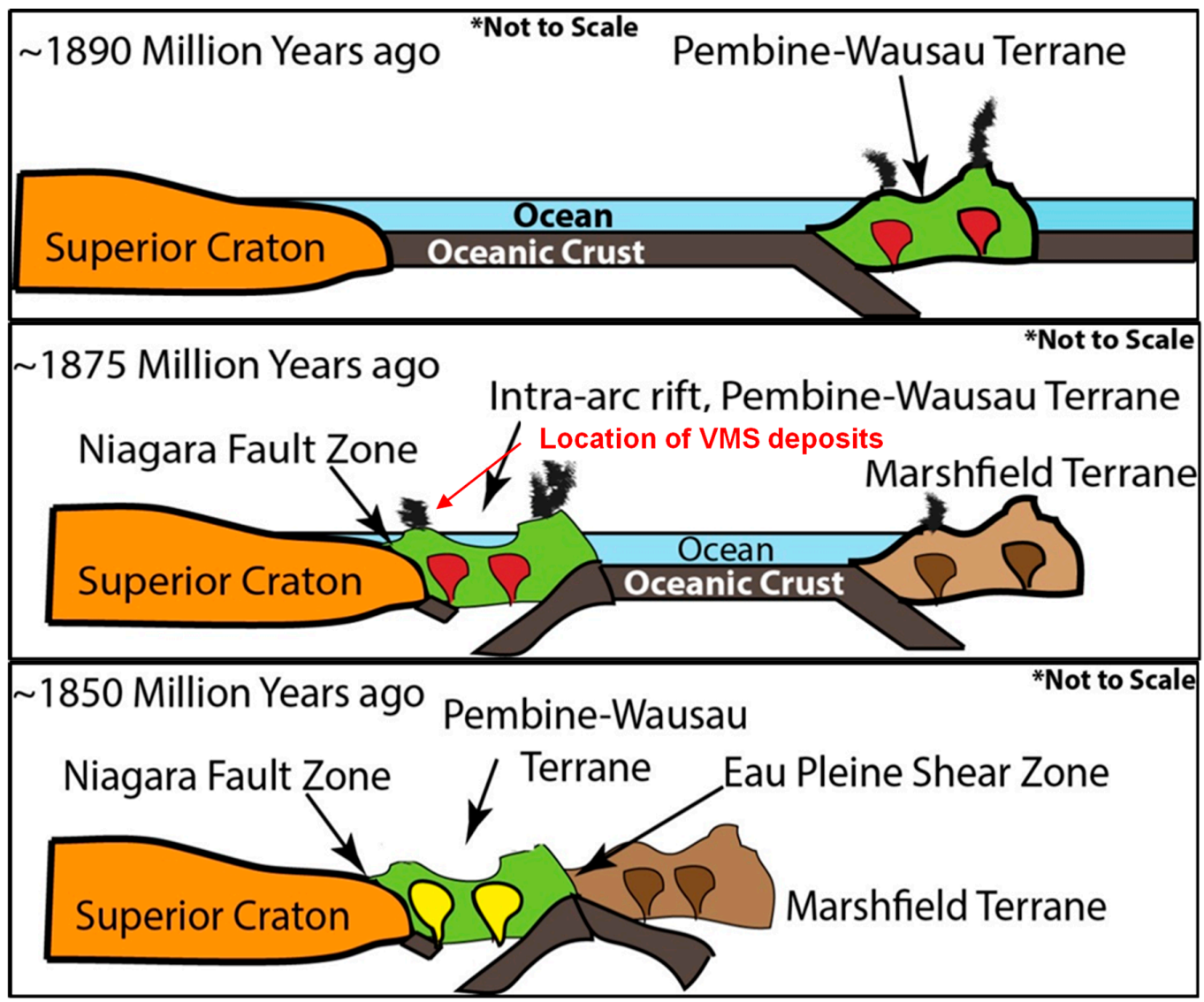

Figure 2. Visual summary of the Penokean Orogeny from Schulz and Cannon [24]. At 1.89 Ga the volcanic arc Pembine-Wausau Terrane approached the Superior Craton by a southward directed subduction. When it collided with the southern margin of the Superior Craton along the Niagara Fault Zone, the subduction stopped. A northward subduction started with the approach of the Marshfield Terrane. This caused extension and the formation of an intra-arc rift in the Pembine-Wausau Terrane. The volcanogenic massive sulfide (VMS) deposits of the Penokean Belt formed during this episode of tectonism. The accretion ended with an eventual collision of the Marshfield Terrane with the Pembine-Wausau Terrane along the Eau Pleine Shear Zone.

It is proposed that at approximately $1.875 \mathrm{Ga}$, the Pembine-Wausau Terrane collided with the southern margin of the Superior Craton and this, according to some workers [24], caused a reversal in the direction of subduction. The new north-directed subduction event possibly facilitated back-arc extension and caused crustal thinning within the accreted Pembine-Wausau Terrane. This caused intra-arc rifting which must have initiated an episode of bimodal calc-alkaline volcanism [24,25]. Some workers [26] favored a model of south-directed subduction but recognized that northward 
subduction beneath the accreted island arcs might also have occurred. In either case, convective circulation of hydrothermal fluids within this back-arc volcanic rift zone caused the formation of a group of VMS deposits oriented approximately in the $\mathrm{E}-\mathrm{W}$ direction. The termination of this back-arc extension and volcanism has been explained by the accretion of the Marshfield Terrane at about $1.850 \mathrm{Ga}[24]$.

The Pembine-Wausau Terrane and the Marshfield Terrane collectively constitute the Penokean Volcanic Belt. The Pembine-Wausau Terrane extends for a strike length of $275 \mathrm{~km}$ across northern Wisconsin into the upper peninsula of Michigan. It hosts a large collection of polymetallic VMS deposits (Figure 3) [25]. These deposits collectively contain more than 100 million tons of identified base and precious metals but most of them have remained undeveloped [27].

DeMatties [25] described three depositional environments in the region between $1.880 \mathrm{Ga}$ and $1.860 \mathrm{Ga}$. These include: (1) The main volcanic-arc sequence, which is the structural core of the complex, (2) a back-arc volcanic-volcaniclastic succession partly composed of mafic volcanic flows, and (3) felsic volcanic successions in the back-arc basin along the flanks of the main volcanic arc. The felsic volcanic succession, and partly the back-arc volcanic successions are the principal hosts of the VMS deposits. The major host rocks of the VMS deposits are altered felsic volcanic-volcaniclastic sequences, composed of dacite-rhyodacite to rhyolitic flows, meta-tuffs, lapilli tuffs, and chemical volcaniclastic sediments. The grade of metamorphism varies from lower greenschist to amphibolite facies. The volcanic-volcaniclastic host rock sequences have suffered extensive hydrothermal alteration. Sericitic alteration is most predominant, but various degrees of silicic and chloritic alteration have also been reported [27-29].

The sulfide ore horizons form layers parallel to the volcanic-volcaniclastic host rock sequences. Stockwork sulfide textures are frequently seen underneath the stratigraphic horizons of the layered massive sulfides. Fine, stringer-type sulfide occurrences are also common within the volcaniclastic layers. The principal sulfide minerals are sphalerite, pyrite, galena, and chalcopyrite.

\subsection{Previous Work}

The geological history of the PVB and the nature of the associated VMS deposits have been studied by several workers, including DeMatties [30], Sims [31], Sims and Carter [32], DeMatties [25], DeMatties and Rowell [33], Schulz and Cannon [24], Quigley [28], Quigley [34], and DeMatties [35]. LaBerge [26] complied and edited a volume on VMS deposits in northern Wisconsin. Schulz et al. [27] reported U-Pb age dates for the Back Forty deposit at $1874 \pm 4$ Ma. Based on zircon U-Pb studies, Quigley [34] reported the age of the Bend deposit at $1872 \pm 0.61 \mathrm{Ma}$, the Horseshoe deposit at $1874.52 \pm 0.66 \mathrm{Ma}$, and the Lynne deposit at $1874.99 \pm 0.68 \mathrm{Ma}$. 


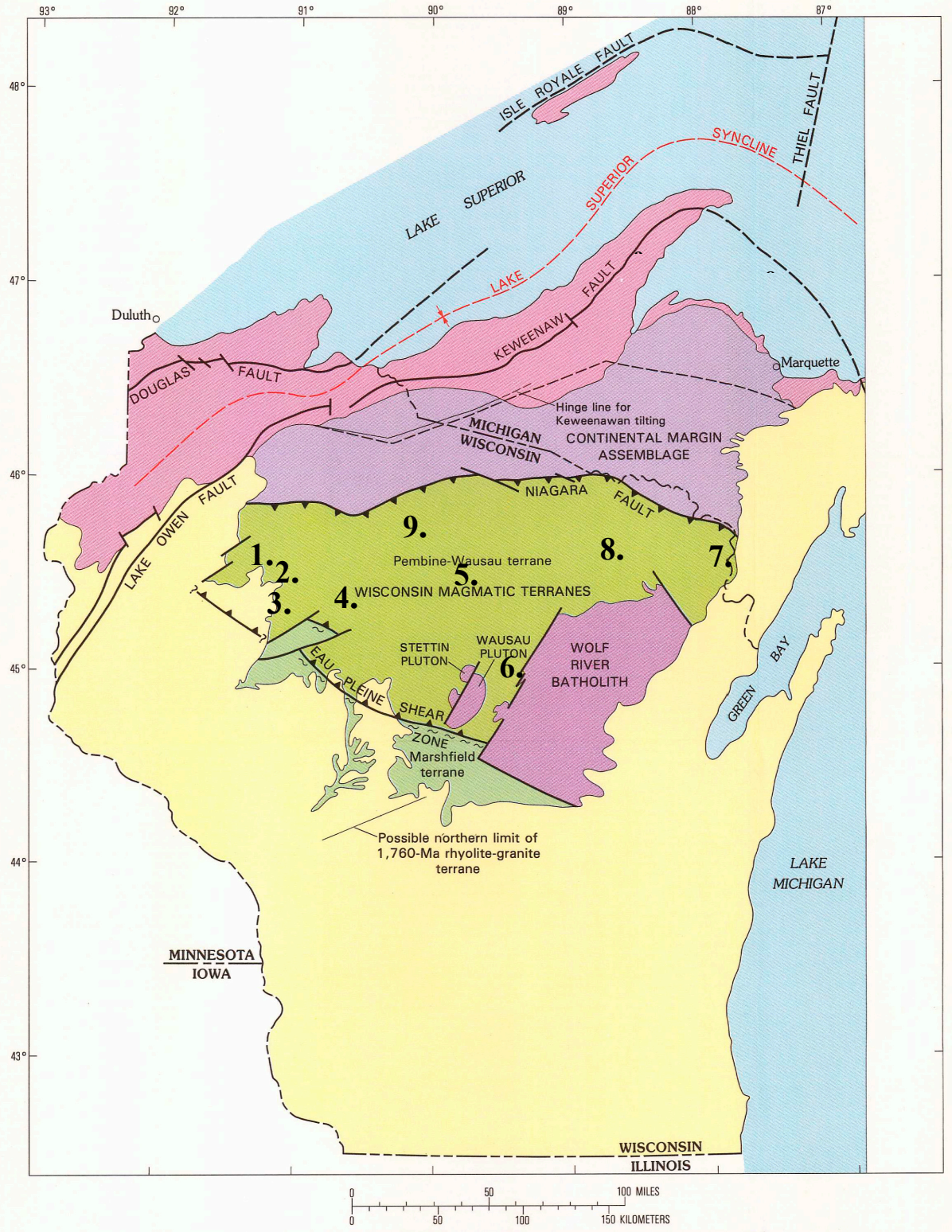

TECTONIC MAP OF SOUTHERN PART OF LAKE SUPERIOR REGION, WISCONSIN AND NORTHERN MICHIGAN

\section{EXPLANATION}

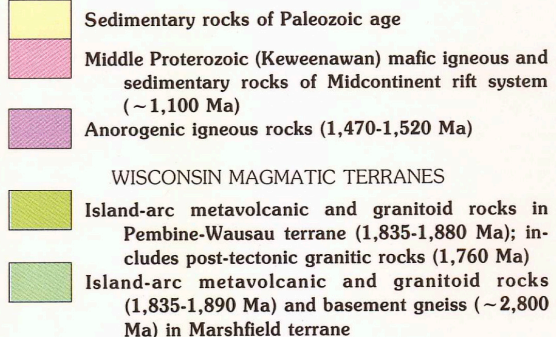
CONTINENTAL MARGIN ASSEMBLAGE

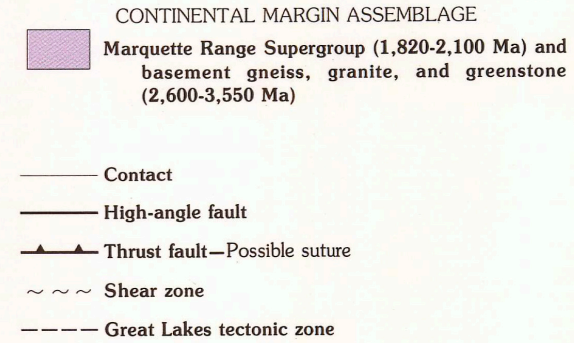

Figure 3. The Penokean Volcanic Belt and the adjoining regions (modified from Sims [31]). The numbers indicate VMS deposits studied in this work: 1. Eisenbrey, 2. Flambeau, 3. Schoolhouse, 4. Bend, 5. Horseshoe, 6. Reef, and 7. Back forty and locations for previous studies used in this work, 8. Crandon [23], and 9. Lynne [36]. 
Geochemical analyses from VMS deposits in the PVB have been conducted on drill core samples from sulfide mineralized units hosted within volcanic strata [29]. Most VMS deposit in the PVB have been classified as bimodal-felsic $[3,4,37]$ and the sulfide ore horizons are primarily hosted in layered sequences of rhyolite and pyroclastic tuff [38]. However, the Horseshoe deposit, in contrast, is characterized by basaltic host rocks [34].

DeMatties [35] described hydrothermal alteration characteristics and supergene enrichment patterns for several VMS deposits and provided latest estimates of ore tonnage and grade. Glacial sediments overlying the Bend deposit were studied by Woodruff [36]. Quigley [28] used XRF, ICP-MS, as well as scanning electron microscope (SEM) analysis of core samples to characterize: (1) Back Forty, (2) Bend, (3) Flambeau, (4) Horseshoe, (5) Lynne, (6) Reef, and (7) Ritchie Creek deposits and presented a detailed stratigraphy and modes of occurrence for these deposits. Zens and Lodge [39] used X-Ray fluorescence (XRF) and Inductively Coupled Plasma Mass Spectrometry (ICP-MS) to characterize the Flambeau deposit.

However, $\delta^{34} S$ values from metallic sulfide minerals from VMS deposits in the PVB are rare. Myers [23] reported $\delta^{34} S$ values from sulfide minerals in the Crandon deposit and these values cluster between -3 and $2 \%$.

In this work we have reported $\delta^{34} S$ values from sulfide minerals in eight more VMS deposits in the PVB. These $\delta^{34} S$ values have then been used to constrain the sources of sulfur and to characterize the chemical composition of Paleoproterozoic seawater in terms of S-isotope ratios.

\section{Methods}

$\delta^{34} S$ values were obtained from sulfide minerals in the mineralized zones from volcanic sequences at the following VMS deposits in the PVB: Back Forty, Bend, Eisenbrey, Flambeau, Horseshoe, Lynne, Reef, and Schoolhouse. A total of 185 samples were collected from various depths based on the nature and texture of sulfide minerals and types of host rocks as encountered in drill cores. Samples from Eisenbrey, Schoolhouse, and Flambeau were collected from the core repository of the Wisconsin Geological and Natural History Survey in Madison, Wisconsin. Samples from Back Forty, Reef, Bend, and Horseshoe were collected from core repositories of Aquila Resources Inc. in northern Michigan and northern Wisconsin.

Drill core samples were inspected and processed for making thin sections. Thin sections were studied under petrographic microscopes and minerals were chosen for analysis. Sample powder was separated from selected sulfide mineral grains from the corresponding thin section billets as shown in Figure 4. The sulfide minerals were drilled out as fine powder using a micro Dremel hand-operated drilling tool. Approximately 0.1 to $0.2 \mathrm{mg}$ of powdered sulfide mineral samples were then weighed in a Sartorius microbalance and placed into $3.5 \times 5 \mathrm{~mm}$ tin capsules. Samples were then mixed with approximately $0.2 \mathrm{mg}$ of $\mathrm{V}_{2} \mathrm{O}_{5}$ flux inside the tin capsules. These tin capsules were then loaded into the sample carousel of a Costech elemental analyzer for combustion at $980{ }^{\circ} \mathrm{C}$. The $\mathrm{SO}_{2}$ gases released were analyzed by a Delta-V continuous flow Isotope Ratio Mass-Spectrometer (IRMS) at the Stable Isotope laboratory in Western Michigan University. The obtained $\delta^{34} S$ values were reported with respect to the "Vienna Canyon Diablo Troilite" (V-CDT) with a $\delta^{34} \mathrm{~S}$ value of $0 \%$. The $\delta^{34} \mathrm{~S}$ values of samples were calculated by the formula:

$$
\delta^{34} \mathrm{~S}=\left(\left({ }^{34} \mathrm{~S} /{ }^{32} \mathrm{~S}_{\text {sample }}-{ }^{34} \mathrm{~S} /{ }^{32} \mathrm{~S}_{\text {standard }}\right) /\left({ }^{34} \mathrm{~S} /{ }^{32} \mathrm{~S}_{\text {standard }}\right)\right) \times 1000 \%
$$



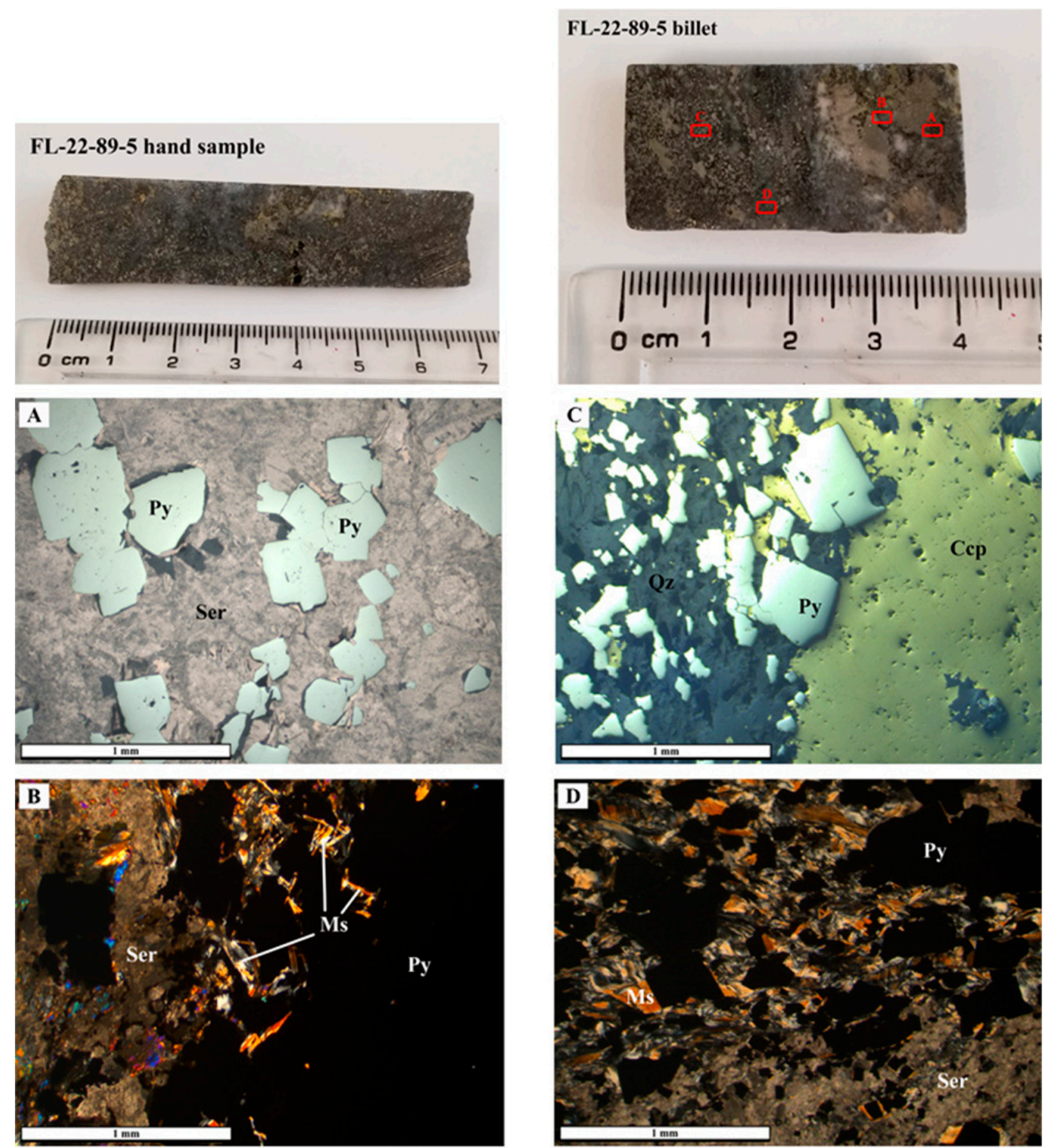

Figure 4. Representative sample and photomicrographs from the Flambeau deposit showing the methods of sample inspection and sample collection for the Isotope Ratio Mass-Spectrometer (IRMS) study. Py = pyrite; Ccp = chalcopyrite; Qz = quartz; Ser = sericite; Ms = muscovite.

The international sulfur isotope reference standards used in the analyses were IAES-S-1 with a $\delta^{34} \mathrm{~S}$ value of $-0.3 \%$ and IAEA-S- 2 with a $\delta^{34} \mathrm{~S}$ value of $21.7 \%$.

Raw sample values were corrected using a multiple-point linear normalization method. For the eight sample runs, this normalization method yielded sample-standard correlation lines with $\mathrm{R}^{2}$ values of 0.99 . The equations produced by these trend lines were used to correct the values relative to V-CDT. The sample reproducibility was $\pm 0.2 \%$ or better.

\section{Results}

$\delta^{34} \mathrm{~S}$ data from 154 sulfide mineral samples from seven VMS deposits, including the data from Lynne by Woodruff [32], are listed in Table 1 and shown as histograms in Figures A1-A7 in the Appendix A. Most values fall within a tight range between 2 and $-2 \%$. The median values for each 
of the seven deposits are shown in Table 2. The median values of Back Forty and Lynne at 2.5 and 2.4 , respectively, are higher than all other deposits. Data from the above eight deposits along with data from Myers [23] were used to create a histogram for the PVB as seen in Figure 5. A large number of data points around $0 \%$ are clearly observable. The deviations of Lynne and Back Forty towards slightly higher values can also be seen.

Table 1. $\delta^{34} \mathrm{~S}$ values from sulfide minerals in the studied VMS deposits.

\begin{tabular}{|c|c|c|c|c|}
\hline Deposit & Sample ID & Depth (m) & Sulfide Mineral & $\delta^{34} \mathbf{S} \%$ \\
\hline \multicolumn{5}{|l|}{ Flambeau } \\
\hline & FL-22-71-5 & 155.45 & pyrite & -1.2 \\
\hline & FL-22-87-6 & 163.68 & sphalerite & -0.7 \\
\hline & FL-22-71-4 & 168.86 & pyrite & -0.1 \\
\hline & FL-22-71-7 & 169.47 & pyrite & -0.3 \\
\hline & FL-22-87-4 & 170.38 & pyrite & -0.1 \\
\hline & FL-22-71-2 & 170.69 & chalcopyrite & -0.8 \\
\hline & FL-22-87-1 & 181.97 & pyrite & -0.7 \\
\hline & FL-22-89-10 & 185.01 & pyrite & -1.2 \\
\hline & FL-22-89-9 & 186.84 & pyrite & -1.3 \\
\hline & FL-22-89-8 & 191.72 & pyrite & -1.1 \\
\hline & FL-22-89-7 & 192.63 & chalcopyrite & 0.3 \\
\hline & FL-22-89-6 & 199.03 & pyrite & -1.1 \\
\hline & FL-22-89-4 & 201.78 & pyrite & 0.4 \\
\hline & FL-22-89-5 & 204.22 & chalcopyrite & -2.1 \\
\hline & FL-22-89-3 & 206.35 & pyrite & -0.8 \\
\hline & FL-22-89-1 & 207.57 & pyrite & -1.2 \\
\hline \multicolumn{5}{|l|}{ Horseshoe } \\
\hline & HS-94-1 & 173.74 & chalcopyrite & -0.5 \\
\hline & HS-94-7 & 241.10 & pyrite & 0.8 \\
\hline & HS-94-8 & 251.16 & pyrite & -0.4 \\
\hline & HS-94-9 & 254.20 & pyrite & 0.2 \\
\hline & HS-94-11 & 258.17 & pyrite & 0.7 \\
\hline & HS-94-10 & 258.47 & chalcopyrite & 0.9 \\
\hline & HS-94-12 & 264.87 & chalcopyrite & 0.4 \\
\hline & HS-94-13 & 267.00 & sphalerite & 0.9 \\
\hline & HS-94-14 & 270.05 & pyrite & 0.6 \\
\hline & HS-94-15 & 272.19 & pyrite & 0.8 \\
\hline \multicolumn{5}{|c|}{ Schoolhouse } \\
\hline & SH-1-5 & 33.22 & pyrite & -3.4 \\
\hline & SH-1-4 & 158.50 & pyrite & 0.6 \\
\hline & SH-1-1 & 160.93 & pyrite & -1.3 \\
\hline & SH-1-3 & 161.24 & pyrite & -2.1 \\
\hline & SH-3-3 & 198.12 & pyrite & 0.1 \\
\hline & SH-3-2 & 204.22 & pyrite & 0.2 \\
\hline & SH-3-1 & 219.15 & pyrite & -1.1 \\
\hline & SH-8-1 & 247.19 & pyrite & 0.3 \\
\hline & SH-11-1 & 248.11 & chalcopyrite & -1.5 \\
\hline & SH-8-2 & 263.35 & chalcopyrite & -1.1 \\
\hline \multicolumn{5}{|l|}{ Eisenbrey } \\
\hline & EI-T-8-3 & 122.22 & pyrite & -0.4 \\
\hline & EI-T-8-5 & 122.22 & pyrite & -0.3 \\
\hline & EI-T-8-2 & 133.20 & pyrite & -0.3 \\
\hline & EI-T-8-4 & 133.20 & pyrite & -0.6 \\
\hline & EI-T-8-1 & 142.95 & chalcopyrite & -0.6 \\
\hline \multicolumn{5}{|l|}{ Reef } \\
\hline & RE-11-11-12 & 16.46 & pyrite & -1.4 \\
\hline & RE-11-11-11 & 19.51 & pyrite & -0.4 \\
\hline & RE-11-11-10 & 24.69 & pyrite & -0.3 \\
\hline & RE-11-11-14 & 26.52 & pyrite & -0.7 \\
\hline & RE-11-11-7 & 28.96 & pyrite & -0.5 \\
\hline
\end{tabular}


Table 1. Cont.

\begin{tabular}{|c|c|c|c|c|}
\hline Deposit & Sample ID & Depth (m) & Sulfide Mineral & $\delta^{34} \mathbf{S} \%$ \\
\hline \multicolumn{5}{|l|}{ Reef } \\
\hline & RE-11-11-8 & 30.48 & pyrite & -0.6 \\
\hline & RE-11-11-9 & 33.22 & pyrite & 0.2 \\
\hline & RE-11-11-5 & 39.62 & pyrite & -0.3 \\
\hline & RE-11-11-4 & 41.61 & pyrite & -0.9 \\
\hline & RE-11-11-3 & 49.07 & chalcopyrite & -0.3 \\
\hline & RE-11-11-2 & 50.90 & chalcopyrite & 1.0 \\
\hline & RE-11-11-18 & 51.21 & pyrite & 1.2 \\
\hline & RE-11-11-1 & 53.04 & pyrite & -1.3 \\
\hline & RE-11-11-13 & 55.47 & pyrite & -0.8 \\
\hline & RE-11-11-6 & 70.10 & pyrite & 1.2 \\
\hline & RE-91-49-6 & 98.15 & pyrite & -0.2 \\
\hline & RE-91-49-5 & 100.89 & pyrite & -0.4 \\
\hline & RE-91-49-8 & 103.63 & pyrite & -1.7 \\
\hline & RE-91-49-7 & 105.16 & pyrite & -1.8 \\
\hline & RE-91-49-12 & 110.95 & pyrite & -2.2 \\
\hline & RE-91-49-19 & 112.47 & pyrite & -1.0 \\
\hline & RE-91-49-9 & 114.91 & pyrite & -1.5 \\
\hline & RE-91-49-10 & 118.57 & pyrite & -0.5 \\
\hline & RE-91-49-15 & 120.40 & pyrite & -0.4 \\
\hline & RE-91-49-14 & 123.75 & pyrite & -0.5 \\
\hline & RE-91-49-13 & 124.05 & pyrite & 0.1 \\
\hline & RE-91-49-11 & 129.84 & pyrite & -2.4 \\
\hline & RE-89-46-3 & 141.43 & pyrite & -1.3 \\
\hline & RE-89-46-2 & 148.44 & pyrite & 0.3 \\
\hline & RE-89-46-1 & 157.28 & pyrite & 1.3 \\
\hline & RE-91-49-18 & 164.59 & pyrite & -0.1 \\
\hline & RE-91-49-17 & 165.51 & pyrite & -0.6 \\
\hline & RE-91-49-3 & 204.52 & pyrite & -0.6 \\
\hline & RE-91-49-2 & 205.13 & pyrite & -1.2 \\
\hline & RE-91-49-1 & 220.68 & pyrite & -3.0 \\
\hline & RE-91-49-4 & 222.81 & pyrite & -1.5 \\
\hline & RE-91-49-16 & 227.99 & pyrite & -0.3 \\
\hline \multicolumn{5}{|l|}{ Bend } \\
\hline & BE-12-01-4 & 106.70 & pyrite & -0.2 \\
\hline & BE-12-01-6 & 112.30 & pyrite & 0.2 \\
\hline & BE-12-01-7 & 119.00 & pyrite & -0.4 \\
\hline & BE-1-17 & 127.41 & chalcopyrite & -1.0 \\
\hline & BE-1-16 & 131.98 & pyrite & -0.6 \\
\hline & BE-12-01-8 & 133.50 & pyrite & 0.2 \\
\hline & BE-1-15 & 136.25 & pyrite & 0.7 \\
\hline & BE-1-14 & 136.86 & chalcopyrite & -0.6 \\
\hline & BE-1-13 & 141.73 & pyrite & -0.3 \\
\hline & BE-1-11 & 142.04 & pyrite & -0.2 \\
\hline & BE-1-12 & 142.65 & pyrite & -0.2 \\
\hline & BE-1-10 & 148.44 & pyrite & -0.7 \\
\hline & BE-1-9 & 150.88 & pyrite & 0.4 \\
\hline & BE-1-8 & 166.42 & pyrite & -0.4 \\
\hline & BE-1-4 & 168.55 & pyrite & 0.0 \\
\hline & BE-1-6 & 168.55 & pyrite & 0.3 \\
\hline & BE-1-5 & 168.86 & pyrite & 0.0 \\
\hline & BE-1-7 & 169.16 & pyrite & -0.4 \\
\hline & BE-1-3 & 193.24 & pyrite & 1.0 \\
\hline & BE-1-2 & 207.87 & chalcopyrite & -2.3 \\
\hline & BE-12-01-12 & 210.00 & pyrite & -0.9 \\
\hline & BE-1-1 & 216.41 & chalcopyrite & -0.6 \\
\hline & BE-12-01-11 & 219.50 & pyrite & 0.4 \\
\hline & BE-12-3 & 242.62 & pyrite & -0.8 \\
\hline & BE-12-1 & 272.49 & pyrite & 0.1 \\
\hline & BE-12-2 & 272.80 & pyrite & 0.5 \\
\hline & BE-12-08-1 & 488.50 & pyrite & 1.2 \\
\hline & BE-12-08-2 & 498.50 & pyrite & 0.0 \\
\hline & BE-12-08-3 & 507.20 & pyrite & -0.5 \\
\hline
\end{tabular}


Table 1. Cont.

\begin{tabular}{|c|c|c|c|c|}
\hline Deposit & Sample ID & Depth (m) & Sulfide Mineral & $\delta^{34} \mathbf{S} \% 0$ \\
\hline \multicolumn{5}{|l|}{ Bend } \\
\hline & BE-12-08-4 & 519.00 & pyrite & -0.2 \\
\hline & BE-12-08-6 & 543.00 & pyrite & -1.2 \\
\hline & BE-12-08-7 & 548.20 & pyrite & -0.1 \\
\hline & BE-12-08-8 & 567.00 & pyrite & -0.6 \\
\hline \multicolumn{5}{|l|}{ Back Forty } \\
\hline & BF-484-1 & 688.4 & pyrite & 1.7 \\
\hline & BF-484-2 & 694.6 & chalcopyrite & 2.8 \\
\hline & BF-484-4 & 706.8 & galena & 1.1 \\
\hline & BF-484-5 & 709.9 & pyrite & 2.4 \\
\hline & BF-484-6 & 718.3 & pyrite & 2.3 \\
\hline & BF-484-6 & 718.3 & chalcopyrite & 1.7 \\
\hline & BF-484-7 & 721.0 & sphalerite & 2.2 \\
\hline & BF-484-8 & 729.0 & pyrite & 2.5 \\
\hline & BF-479-1 & 792.5 & pyrite & 3.1 \\
\hline & BF-479-2 & 793.1 & pyrite & 3 \\
\hline & BF-479-3 & 795.1 & pyrite & 2.9 \\
\hline & BF-479-4 & 799.3 & pyrite & 2.7 \\
\hline & BF-479-5 & 802.5 & sphalerite & 2.5 \\
\hline & BF-479-6 & 808.1 & pyrite & 2.5 \\
\hline & BF-479-7 & 813.5 & sphalerite & 2.1 \\
\hline & BF-479-8 & 817.0 & pyrite & 3 \\
\hline & BF-479-9 & 817.2 & chalcopyrite & 1.5 \\
\hline \multicolumn{5}{|l|}{ Lynne } \\
\hline & LN 90-12 & 26.06 & sphalerite & 2.3 \\
\hline & LN 90-12 & 26.52 & pyrrhotite & 3.4 \\
\hline & LN 90-12 & 27.43 & sphalerite & 2.2 \\
\hline & LN 90-28 & 52.27 & pyrrhotite & 4.5 \\
\hline & LN 90-12 & 53.34 & sphalerite & 1.5 \\
\hline & LN 90-7 & 76.20 & sphalerite & 2.2 \\
\hline & LN 90-16 & 97.84 & sphalerite & 3.1 \\
\hline & LN 90-16 & 104.24 & pyrrhotite & 1.4 \\
\hline & LN 90-18 & 108.20 & sphalerite & 2.7 \\
\hline & LN 90-18 & 111.56 & sphalerite & 2.0 \\
\hline & LN 90-16 & 111.86 & pyrrhotite & 1.5 \\
\hline & LN 90-7 & 114.00 & sphalerite & 2.3 \\
\hline & LN 90-16 & 114.30 & pyrrhotite & 2.8 \\
\hline & LN 90-7 & 118.26 & sphalerite & 3.4 \\
\hline & LN 90-7 & 121.62 & sphalerite & 1.7 \\
\hline & LN 90-16 & 131.37 & sphalerite & 1.5 \\
\hline & LN 90-7 & 136.25 & sphalerite & 2.4 \\
\hline & LN 90-16 & 138.99 & sphalerite & 3.4 \\
\hline & LN 90-16 & 144.02 & sphalerite & 2.2 \\
\hline & LN 90-18 & 161.24 & sphalerite & 2.0 \\
\hline & LN 90-40 & 164.59 & pyrrhotite & 3.3 \\
\hline & LN 90-40 & 175.26 & sphalerite & 3.8 \\
\hline & LN 90-40 & 175.26 & pyrrhotite & 3.6 \\
\hline & LN 90-18 & 175.87 & galena & 0.7 \\
\hline & LN 90-40 & 186.84 & pyrrhotite & 3.4 \\
\hline & LN 90-40 & 220.98 & galena & 1.1 \\
\hline
\end{tabular}

Table 2. Summary of $\delta^{34} S$ data from eight deposits.

\begin{tabular}{cccc}
\hline Deposit & Number of Samples & $\boldsymbol{\delta}^{34} \mathbf{S}$ Range $(\% 0)$ & Median \\
\hline Flambeau & 16 & -2.1 to 0.4 & -0.8 \\
Horseshoe & 10 & -0.5 to 0.9 & 0.7 \\
Schoolhouse & 10 & -3.4 to 0.6 & -1.1 \\
Eisenbrey & 5 & -0.6 to -0.3 & -0.4 \\
Reef & 37 & -3.0 to 1.3 & -0.5 \\
Bend & 33 & -2.3 to 1.2 & -0.2 \\
Back Forty & 17 & 1.1 to 3.1 & 2.5 \\
Lynne & 26 & 0.7 to 4.5 & 2.4 \\
\hline
\end{tabular}




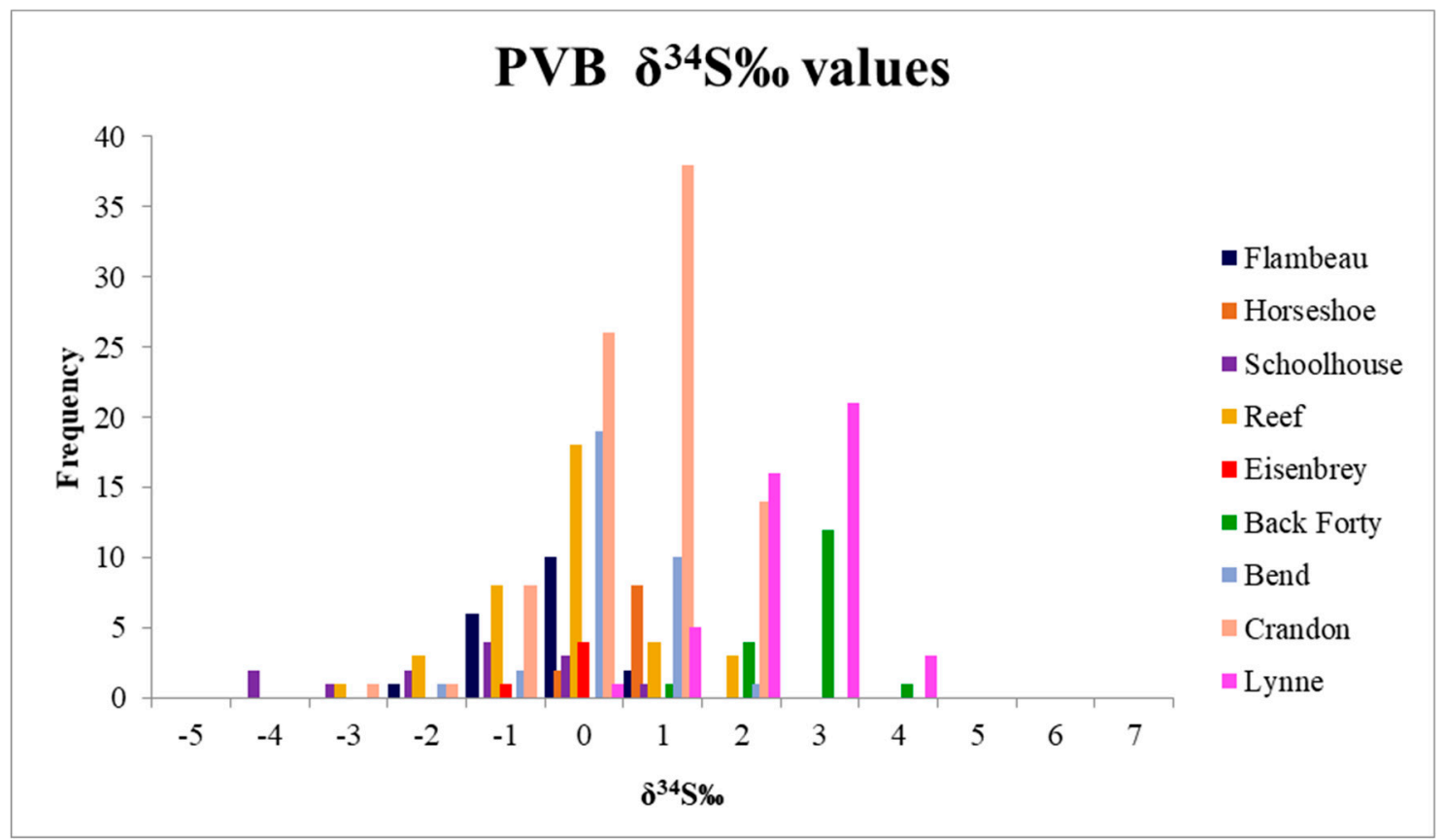

Figure 5. Combined histogram for all nine VMS deposits used in this work. Crandon data from Myers [23] and Lynne data from Woodruff [36].

For each deposit, data points are found to cluster within small ranges regardless of the type of mineral, sample depth, and nature of the host rock. This can be further verified by the $\delta^{34} \mathrm{~S} v$ s. depth plots for the studied deposits in Figures A8-A14 in the Appendix A. For Horseshoe, Bend, Flambeau, and Reef deposits, the sample locations within the host rocks $[28,33]$ can be seen, as encountered in the studied drill cores.

\section{Discussion}

\subsection{Sulfur Isotope Signatures in VMS Deposits}

Among the principal reservoirs of sulfur, $\delta^{34} S$ values of magmatic sulfur tend to cluster around $0 \%$ [11,40,41]. Pristine mid-oceanic ridge basalts have a $\delta^{34} S$ of $0.3 \pm 0.5 \%$ [42]. Minor deviations between 2 and $-2 \%$ are still regarded as representatives of a magmatic source. The magmatic sulfur could be precipitated directly from a mantle-derived magma or could be remobilized from magmatic rocks and precipitated by a subsequent magmatic event.

Secondly, sulfur from seawater sulfate and sulfate introduced from shallow marine evaporite deposits mostly show higher $\delta^{34} \mathrm{~S}$. Oxidation reactions involving reduced sulfur from magmatic sources have resulted in a $\delta^{34} S$ value of $21.0 \pm 0.2 \%$ for dissolved sulfate in modern oceans [43]. Due to the enormous volume of the oceans, the dissolved sulfur in the oceanic water is an important reference reservoir to evaluate sulfur isotope variations in ore-forming systems throughout geological time, particularly for VMS deposits [11-13]. In the geological record, $\delta^{34} S$ values of sulfate in ancient oceans, as recorded in shallow marine evaporite sequences have evolved from around $4.0 \%$ at $3.4 \mathrm{Ga}$ to a high of 35\% during Cambrian [44].

Thirdly, sulfur isotope fractionation caused by sulfate-reducing bacteria [45], or by abiotic thermochemical reduction of aqueous sulfate [8] have large fractionation factors and in an open-system these are known to produce $\delta^{34} S$ values in pyritic black shales as low as $-27 \%$ [46]. Thus, extremely low $\delta^{34} \mathrm{~S}$ signatures could possibly mean substantial contribution of diagenetic sulfur into the ore-forming system.

In this work, the observed $\delta^{34} S$ ratios from the PVB have been used to evaluate possible contributions of sulfur from the above reservoirs. However, the interpretations of $\delta^{34} S$ signatures 
of oceanic sulfide deposits in Archean and Proterozoic have been highly debated. This stems from the paucity of information about the chemical composition of seawater in ancient Earth. Huston [9] and Huston et al. [10] showed temporal variations of $\delta^{34} S$ in VMS deposits (Figure 6) and noted that the available $\delta^{34} \mathrm{~S}$ data from Archean and Proterozoic VMS deposits plot close to 0\%. Seal [11] explained that before the onset of oxygenation of the atmosphere, $\delta^{34} S$ values of hydrothermal sulfide and sulfates clustered near $0 \%$. Then, starting from $2.4 \mathrm{Ga}$ the $\delta^{34} \mathrm{~S}$ from hydrothermal sulfide and sulfate increased gradually and encompassed progressively larger ranges.

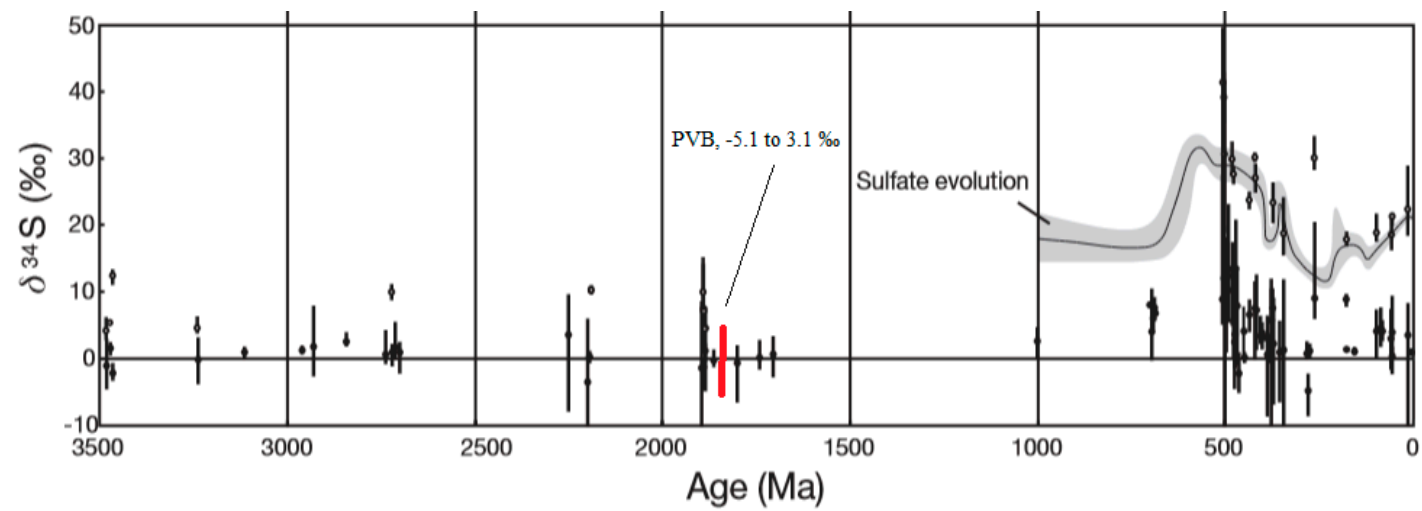

Figure 6. Change in $\delta^{34} \mathrm{~S}$ values from VMS deposits through geologic time as compiled by Huston et al. [10]. The timing and observed range of values from the PVB are indicated in red.

However, there are reported occurrences of VMS deposits in Archean and Proterozoic, where $\delta^{34} \mathrm{~S}$ values depart considerably from $0 \%$. These include the Archean Gossan Hill VMS deposit in Western Australia, where the $\delta^{34} \mathrm{~S}$ varies between -1.6 and 7.8\% [15], and the Mesoproterozoic Areachap Group in South Africa, where the $\delta^{34} \mathrm{~S}$ values range between 3.0 and $8.5 \%$ [17].

\subsection{Distribution of $\delta^{34} S$ Ratios in the PVB}

As seen in Table 1 , the $\delta^{34} \mathrm{~S}$ ratios obtained from eight VMS deposits in the PVB range between -3.4 and $4.5 \%$, and it is evident from Table 2 that the $\delta^{34} \mathrm{~S}$ values cluster within small ranges. Thus, in this work, the median value for each deposit is used as a representative value of that deposit. The $\delta^{34} \mathrm{~S}$ ratios for six of the eight deposits: Flambeau, Horseshoe, Schoolhouse, Eisenbrey, Reef, and Bend vary between -3.4 and $1.3 \%$ but Lynne and Back Forty show heavier values up to $4.5 \%$. The $\delta^{34} S$ values from the Crandon deposit, as reported by Myers [23] cluster closely around $0 \%$ with a median of $0.9 \%$. While the median values of most deposits are quite close to $0 \%$, the medians for Back Forty and Lynne are relatively higher, at 2.5 and $2.4 \%$, respectively.

It is clear from sample histograms in Figures A1-A7 (in the Appendix A) and from $\delta^{34} S$ vs. depth relationships in Figures A8-A14 (in the Appendix A), that $\delta^{34} S$ values do not show any relationship with the types of sulfide minerals and host rocks. However, the values consistently cluster within small ranges. We interpret that the $\delta^{34} S$ values represent ambient geochemical conditions of hydrothermal ore-fluids at time of formation of these deposits and thus provide useful constraints on the sources of sulfur.

\subsection{Possible Sources of Sulfur in the PVB}

Being located in an intra-arc rift setting of the Pembine-Wausau Terrane, the origin of the VMS deposits in the PVB is clearly related to the volcanism caused by back-arc extension of the Pembine-Wausau Terrane in response to a north-directed subduction event along its southern margin around $1.875 \mathrm{Ga}$ (Figure 2) [24]. The Pembine-Wausau Terrane is a volcanic-arc principally composed of tholeiitic basalt and basaltic andesite overlain by calc-alkaline volcanic rocks such as andesite and rhyolite [26,47]. It is evident that this rift-zone within the Pembine-Wausau Terrane received heat-flux 
from the underlying mantle wedge which caused partial melting of the mafic to intermediate volcanic basement rocks. This led to a renewed phase of volcanism which resulted in the formation of the PVB. The observed host rocks of VMS deposits in the PVB are rhyolite, rhyodacite, and andesite, with occasional basaltic flows $[25,26,28,35]$. Thus, sulfur in the ore-fluids of VMS deposits in the PVB must have been partially derived from pre-existing volcanic basement rocks. This is supported by the strong overlap of $\delta^{34} \mathrm{~S}$ values between -3.4 and $4.5 \%$ in the PVB with the known mantle range of $0 \pm 2 \%$. However, it is intuitive that a substantial portion of sulfur might also have originated from the ambient seawater.

It is important to note that the occurrence of pyritiferous black shale or its metamorphic equivalent in the intra-arc rift setting of the PVB is extremely rare [30]. Moreover, the observed $\delta^{34} S$ values in the PVB are much higher than the known ranges of diagenetic pyrite. Thus, from the above considerations it is apparent that sulfur in the ore-forming hydrothermal fluids in the PVB originated from a combination of magmatic and seawater sulfur reservoirs. This supports the proposition by Franklin et al. [3], that sulfur reservoirs for volcanic arcs usually include primitive mantle-derived volcanic rocks and continent-derived sediments or their recycled products.

\subsection{Implications on Seawater Chemistry}

While there has not been any significant temporal variation of $\delta^{34} \mathrm{~S}$ for magmatic sulfur, the variations for the seawater sulfate reservoir deserves special consideration. As mentioned above, there is very little information about seawater composition in lithological records from the Archean and Proterozoic. It was only after $0.7 \mathrm{Ga}$, that the oxygen content of the atmosphere increased steadily which led to the rapid and progressive rise of $\delta^{34} S$ to its present value at about 21.0\%o [11,48].

Oxidative continental weathering after 2300 Ma resulted in the influx of sulfate to seawater $[49,50]$. Huston et al. [10] theorized that sulfate concentration in the Proterozoic seawater was limited to the shallowest levels and the condition was suboxic at depth. The change of seawater to oxidative conditions throughout the water column occurred from the time of precipitation of the Banded Iron Formations.

This interpretation strengthens the theory of sulfur-poor Paleoproterozoic seawater. This also supports the argument that magmatic sulfur was the predominant source of sulfur for Archean and Proterozoic VMS deposits. If there was partial contribution of sulfur from dissolved seawater sulfate, the $\delta^{34} S$ must have been close to the mantle range.

The geographic distribution of median $\delta^{34} S$ values for the studied deposits in the PVB are shown in Figure 7 . There seems to be a consistent rise in $\delta^{34} S$ from southwest to northeast. Back Forty and Lynne in the north have the highest median values of 2.5 and 2.4, respectively, while Schoolhouse has the lowest. It is interesting to note that this geographic distribution pattern and the inferred $\delta^{34} S$-contours (Figure 7) closely mimic the known orientation of the continental margin in the southernmost part of the Superior Craton. This supports the idea that oxidative conditions of seawater preferentially existed at shallow water in the continental margin along the paleo-shoreline. Thus, a higher occurrence of seawater sulfate with heavier $\delta^{34} S$ values might have caused the observed distribution. However, additional data is needed from more closely spaced intervals in the region to confirm this assertion. 


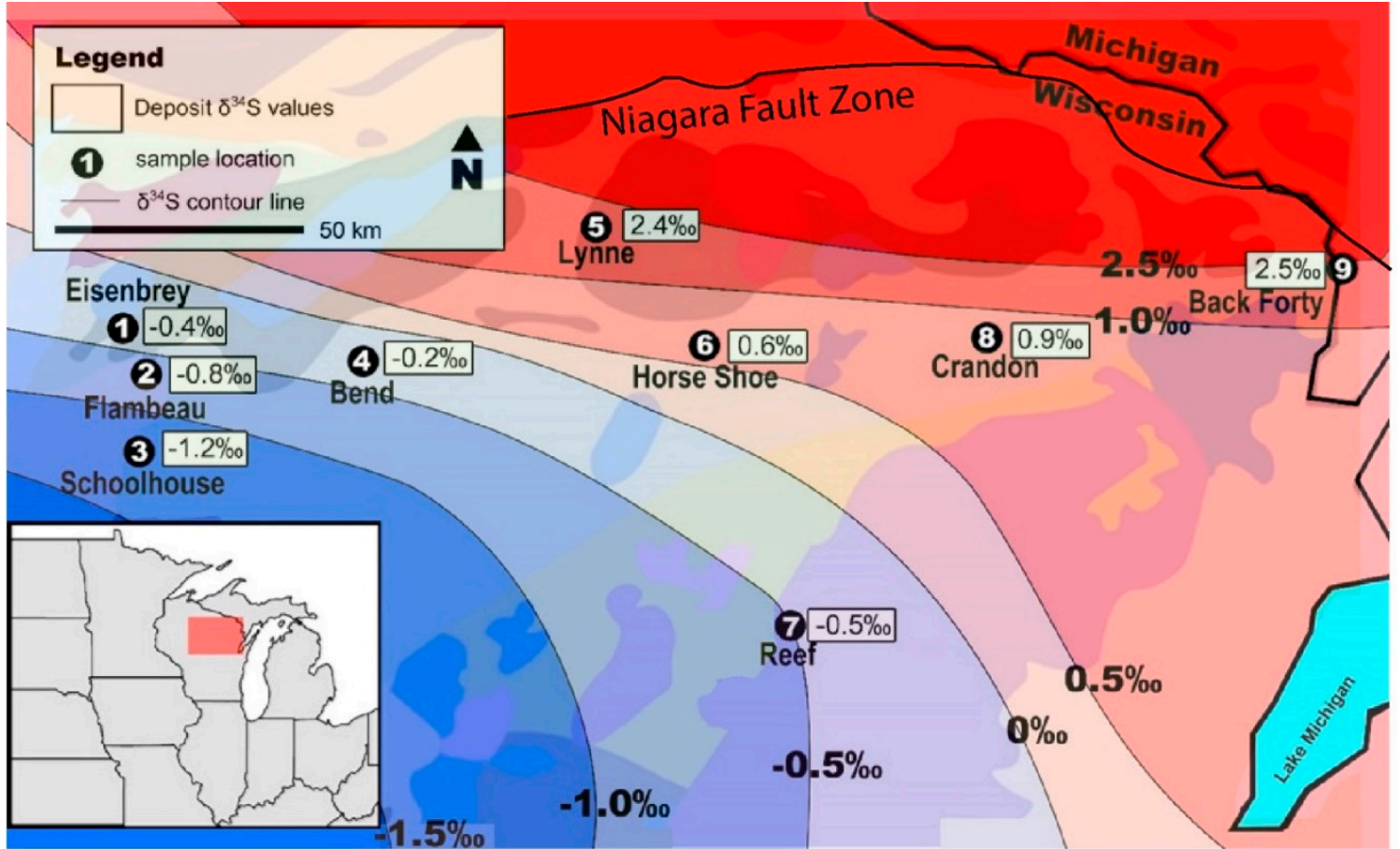

Figure 7. Locations of the eight studied VMS deposits in the PVB [25] and the median $\delta^{34}$ S\% values obtained from these deposits. Darker colors in the background represent principal locations of volcanism in the PVB. The map depicts a consistent regional change in S-isotope signatures. Color transition from blue to red indicates increasing $\delta^{34} \mathrm{~S}$. The trend of gradual increase of $\delta^{34} \mathrm{~S}$ in a northeasterly direction could indicate a relatively higher supply of ${ }^{34} \mathrm{~S}$ from the continental margin which was located along the Niagara Fault Zone in the northern margin of the PVB [24].

\section{Conclusions}

1. $\delta^{34} \mathrm{~S}$ values of sulfide minerals in the mineralized zones in VMS deposits at the Paleoproterozoic Penokean Volcanic Belt are characterized by consistently narrow ranges around $0 \%$. The $\delta^{34} \mathrm{~S}$ values have no relationship with the nature of host rocks, types of sulfide minerals, and textural characteristics.

2. The clustering of values around $0 \%$ indicates the origin of sulfur predominantly from a magmatic source. Since VMS deposits are precipitated on the seafloor, the contribution of sulfur from seawater sulfate deserves special importance.

3. $\delta^{34} S$ values of seawater sulfate in the Paleoproterozoic are poorly constrained, but $\delta^{34} S$ values close to the magmatic range have been proposed. Thus, there might have been a limited supply of sulfur from seawater sulfate at shallow water levels, but the $\delta^{34} S$ value of sulfur from this source must have been close to the magmatic range.

4. The geographic distribution of $\delta^{34} \mathrm{~S}$ in the PVB shows an increasing trend towards the direction of the continental margin in the north. This might indicate a modest degree of derivation of sulfur from oxidized shallow water levels near the continental margin.

Author Contributions: This work is based on MS thesis projects done by Nicholas Moleski and Anthony Boxleiter with the supervision of Joyashish Thakurta. Sample collection, inspection, data generation, and initial interpretations were done by Nicholas Moleski and Anthony Boxleiter and were compiled in their MS theses. Joyashish Thakurta combined the data, made the final interpretations, and wrote the manuscript.

Funding: This research received no external funding.

Acknowledgments: We express our sincere gratitude to Valerie Stanley and Esther Stewart from Wisconsin Geological Survey, and Tom Quigley and Eric Quigley from Aquila Resources Inc. for giving us access to drill core samples used in this study. Laurel Woodruff from US Geological Survey helped us enormously by giving 
us access to a database of S-isotope values from her independent study. Klaus Schulz and Bill Cannon from the US Geological Survey provided useful advice. Robert Lodge from the University of Wisconsin Eau Claire and Christian Schardt from the University of Minnesota Duluth made thoughtful comments on preliminary presentations of the work. The structure and the content of the manuscript have been substantially improved based on suggestions by two anonymous reviewers. Robb Gillespie, Peter Voice, and R.V. Krishnamurthy gave us feedback on early compilations of our results.

Conflicts of Interest: The authors declare no conflict of interest.

\section{Appendix A}

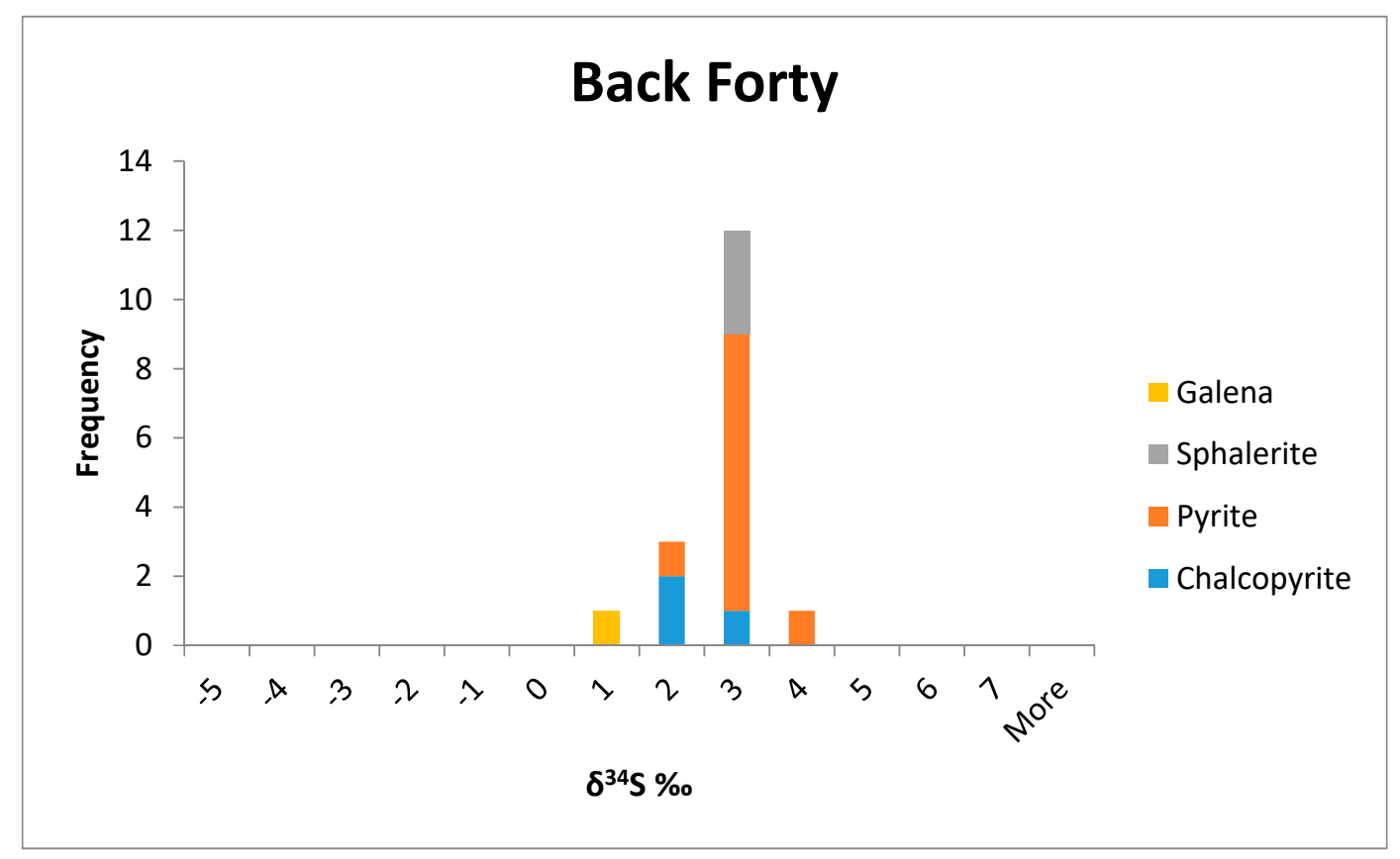

Figure A1. Histogram for Back Forty deposit.

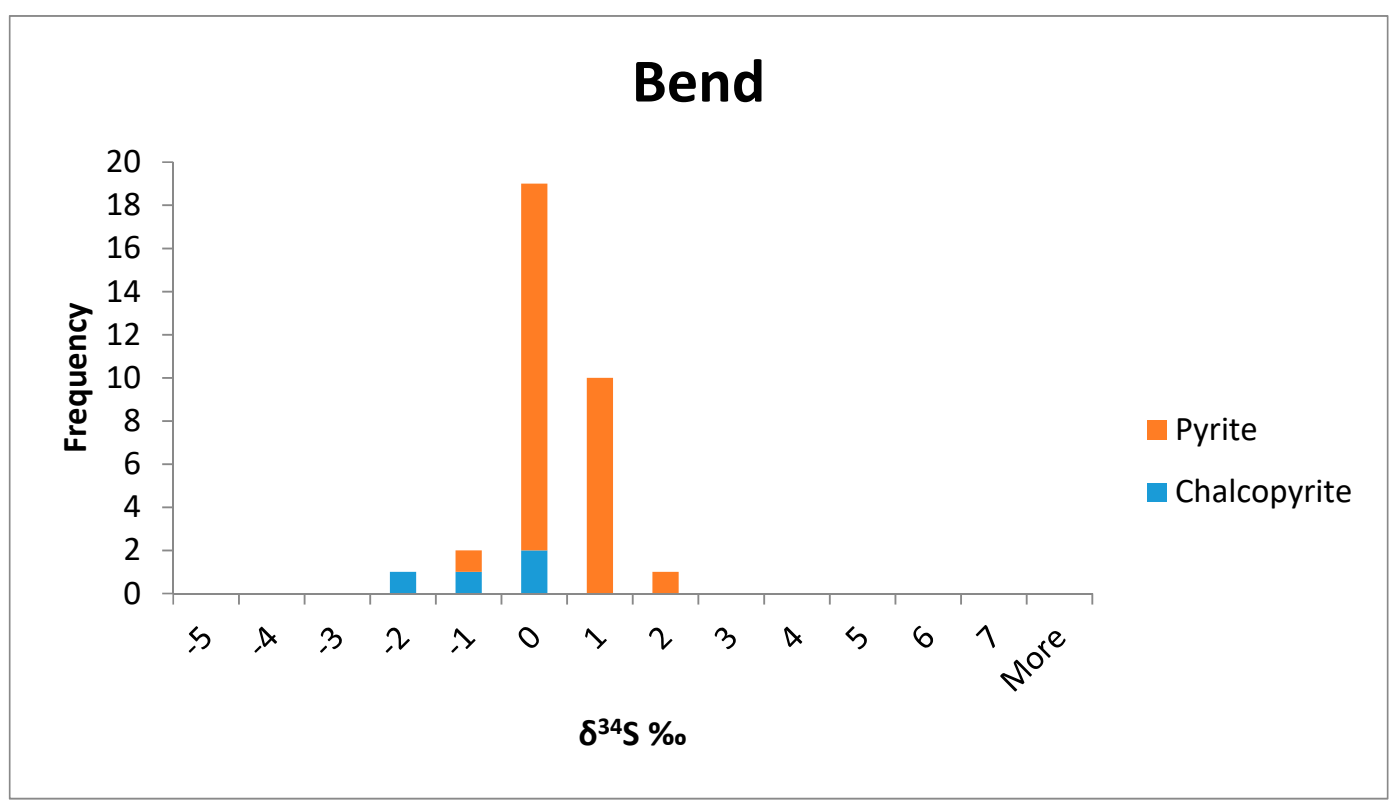

Figure A2. Histogram for Bend deposit. 


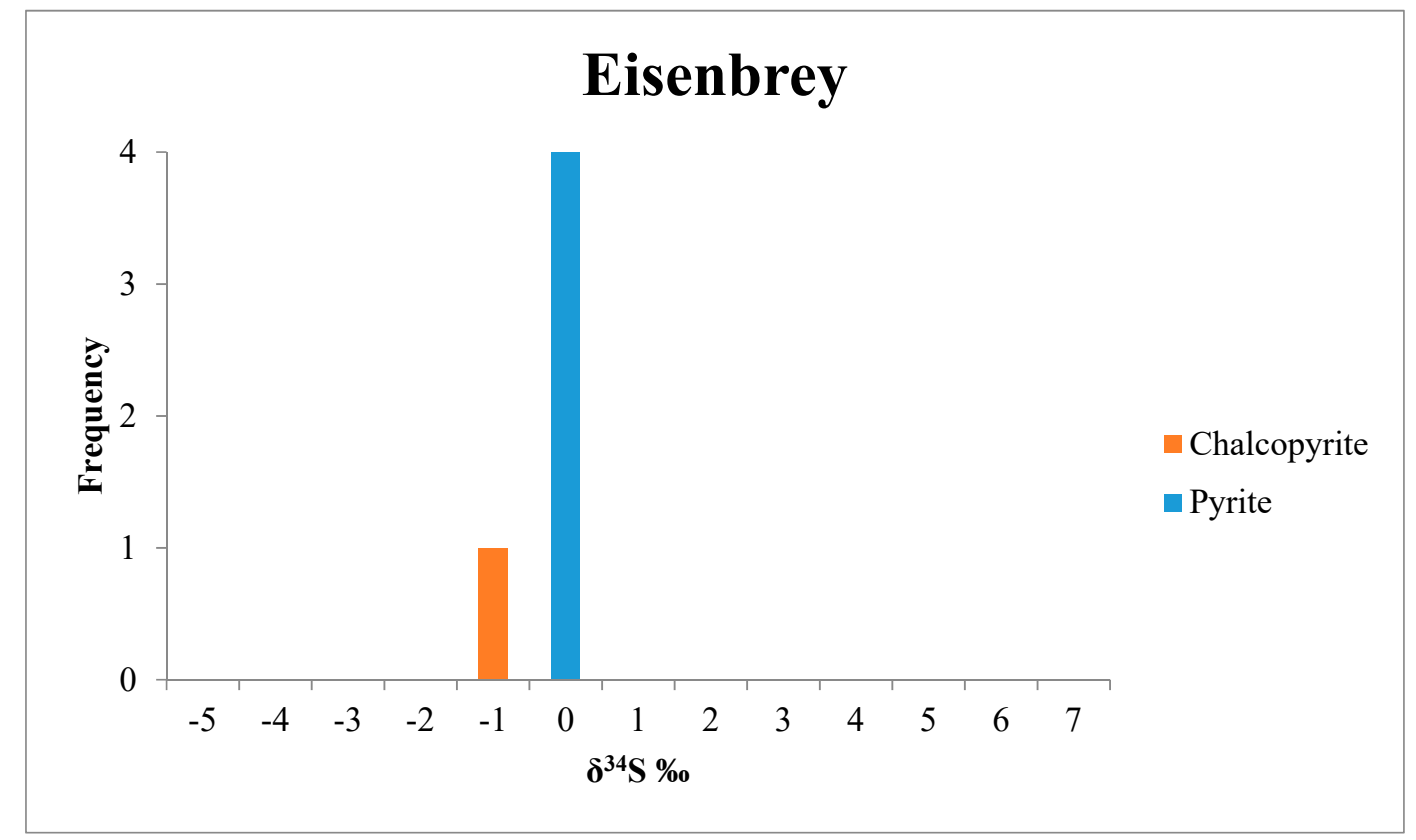

Figure A3. Histogram for Eisenbrey deposit.

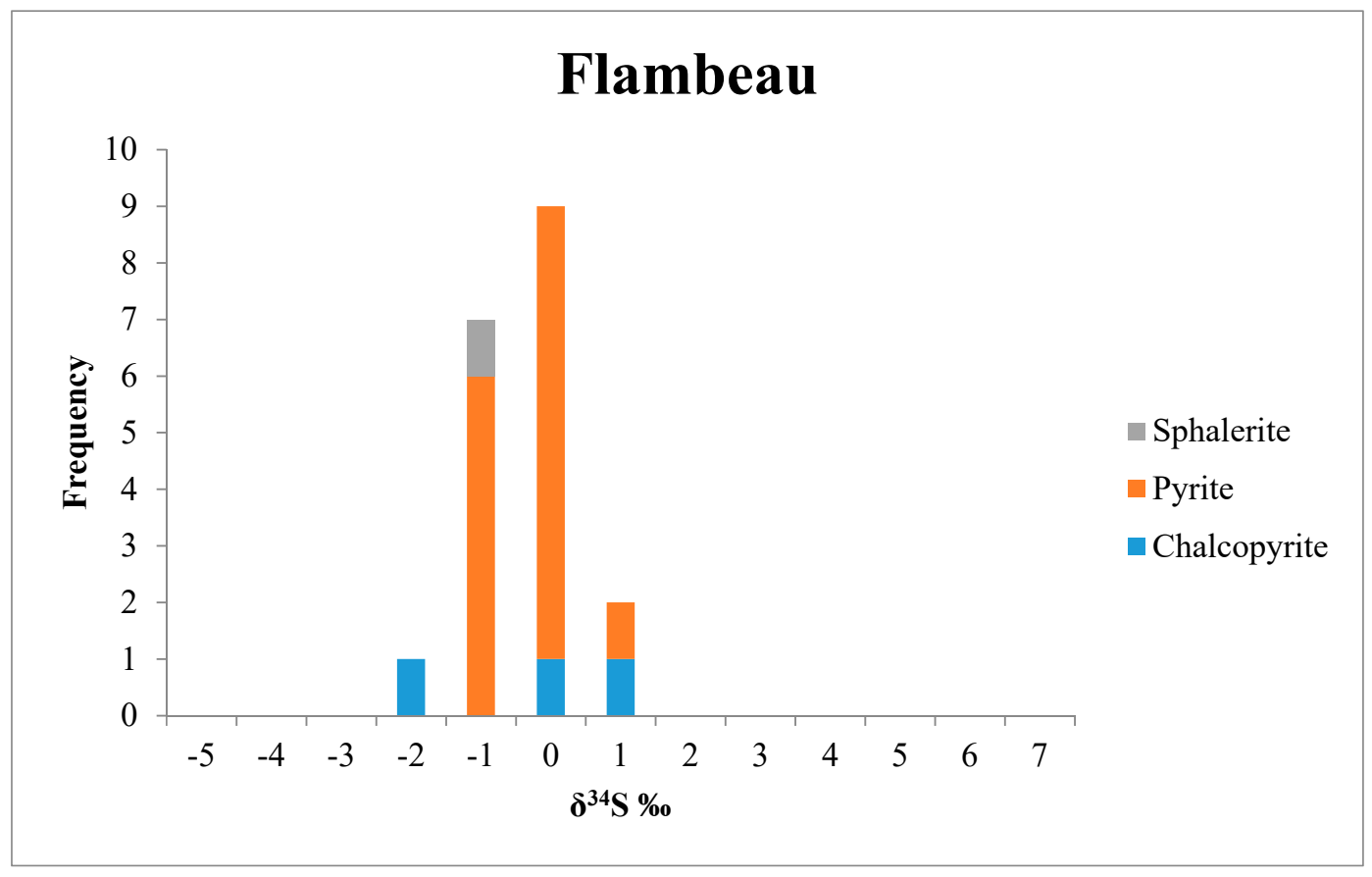

Figure A4. Histogram for Flambeau deposit. 


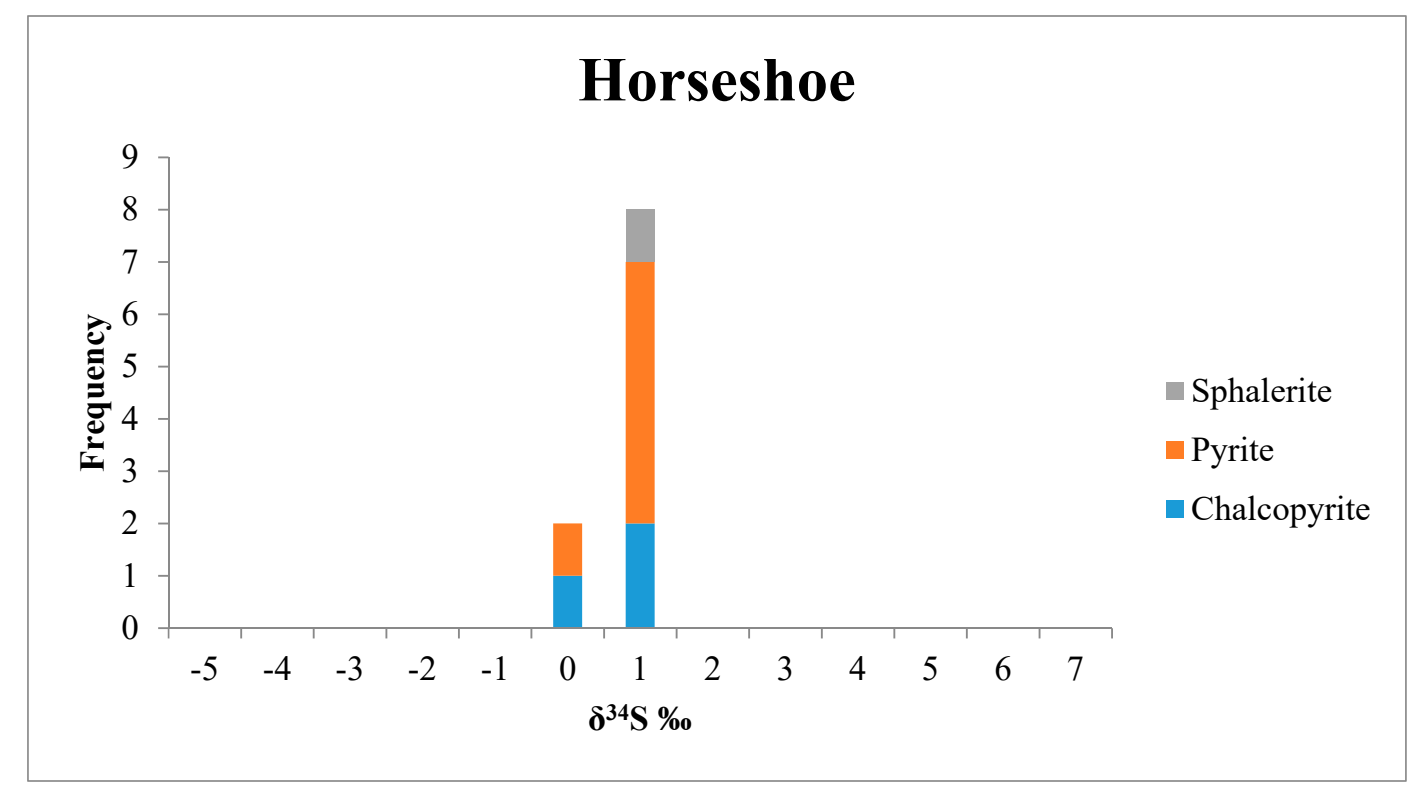

Figure A5. Histogram for Horseshoe deposit.

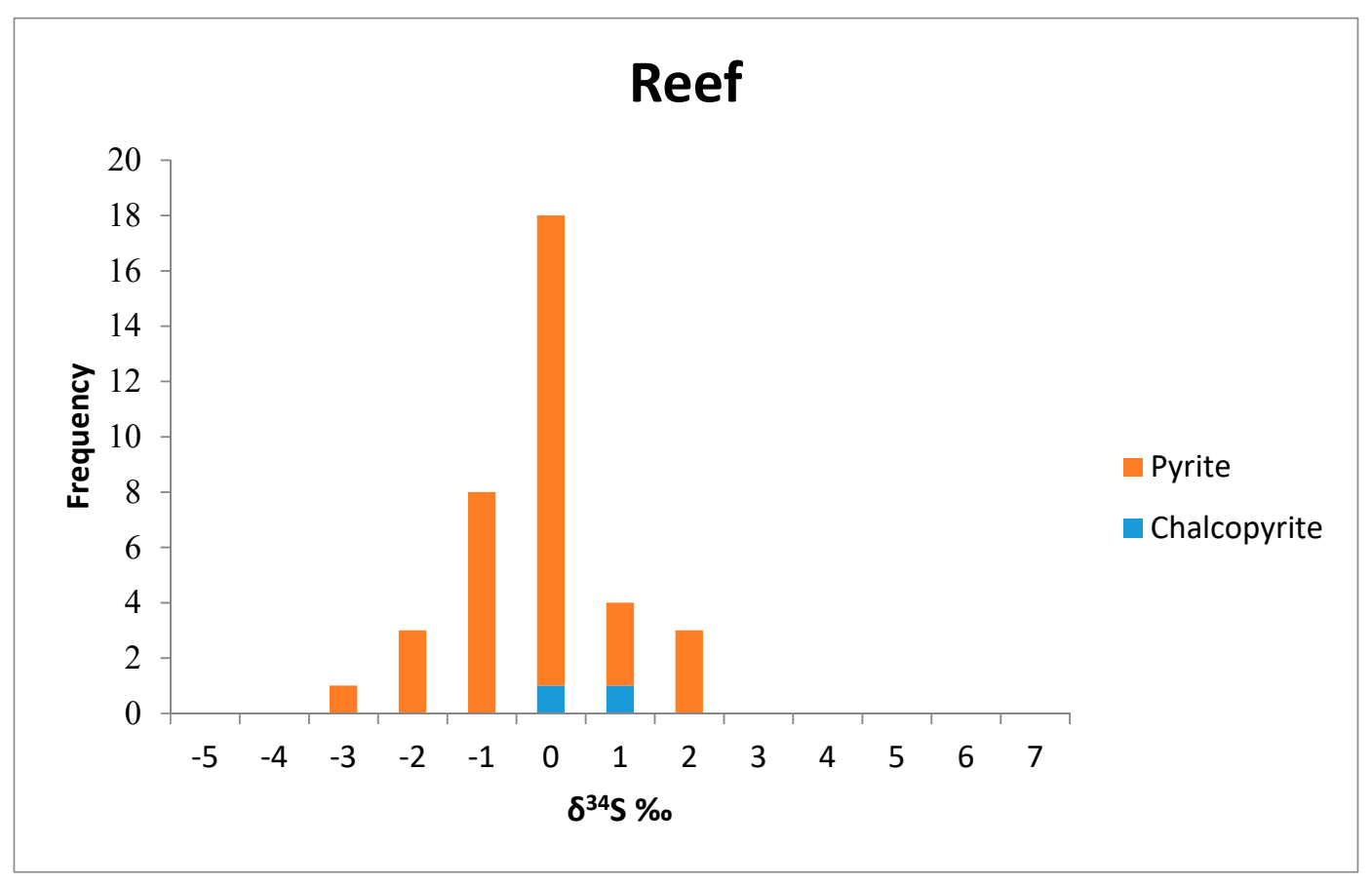

Figure A6. Histogram for Reef deposit. 


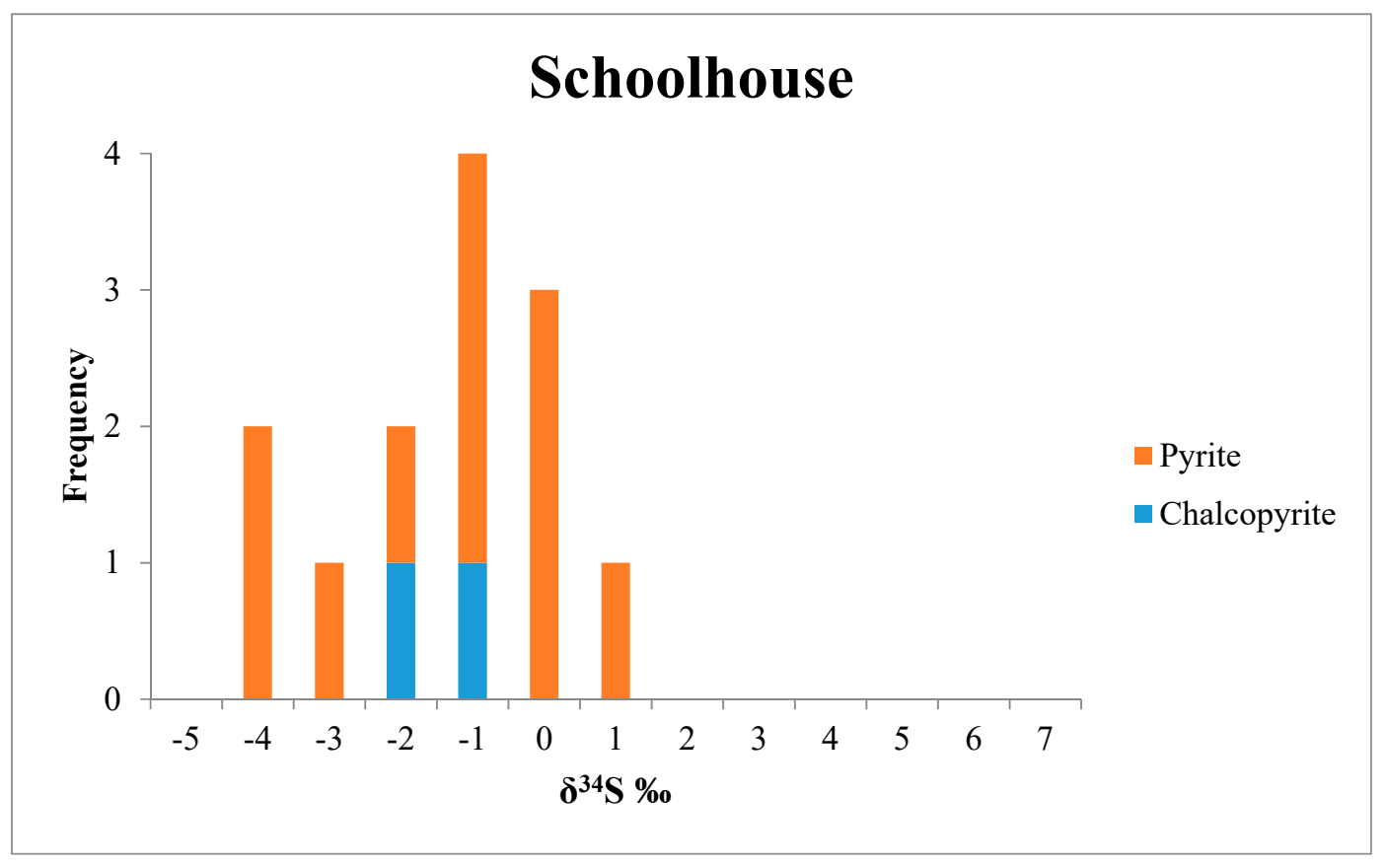

Figure A7. Histogram for Schoolhouse deposit. 

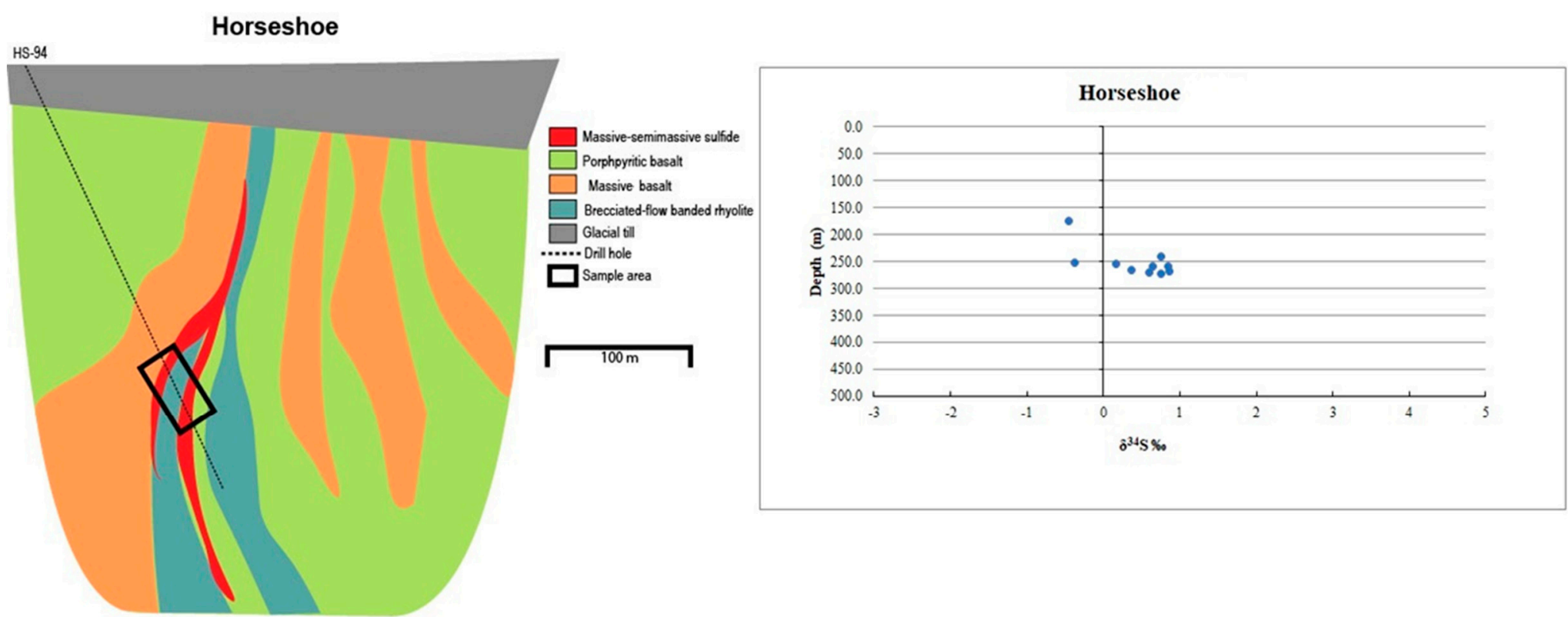

Figure A8. $\delta^{34}$ S vs. depth for Horseshoe deposit samples. The cross section displays the lens of massive sulfide within the sequence. Stratigraphy from Quigley [26]. 


\section{Bend}
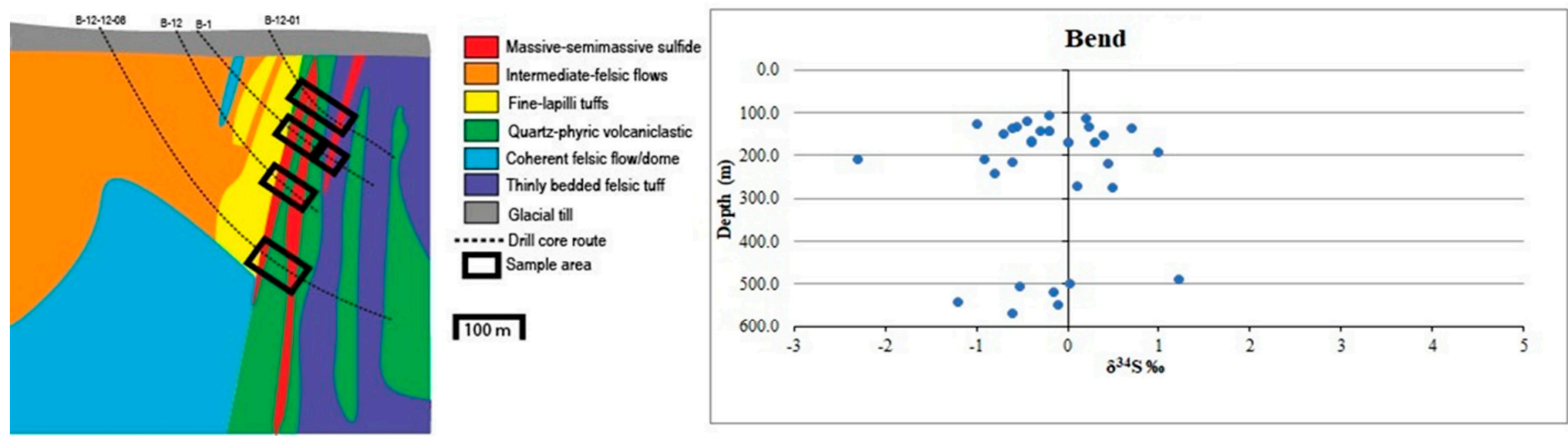

Figure A9. $8^{34} S$ vs. depth for Bend deposit. Stratigraphy from DeMatties and Rowell [24] and Quigley [26]. 

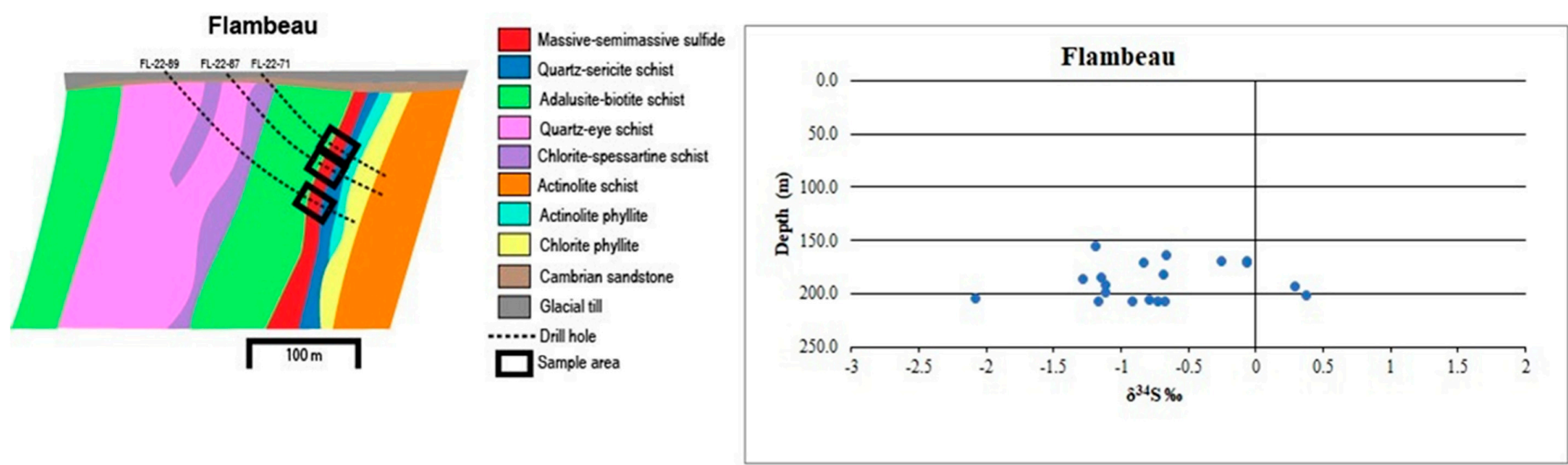

Figure A10. $\delta^{34} S$ vs. depth for samples from Flambeau deposit. Stratigraphy from Quigley [26].
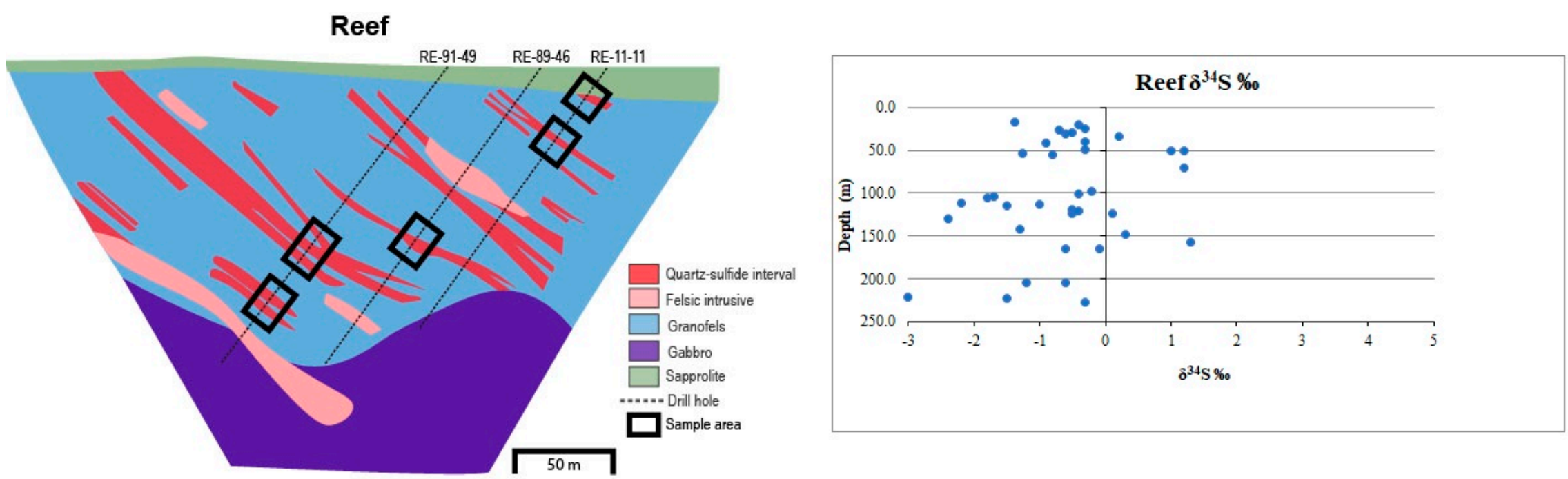

Figure A11. ${ }^{34} S$ vs. depth for Reef deposit. Stratigraphy from Quigley [26]. 


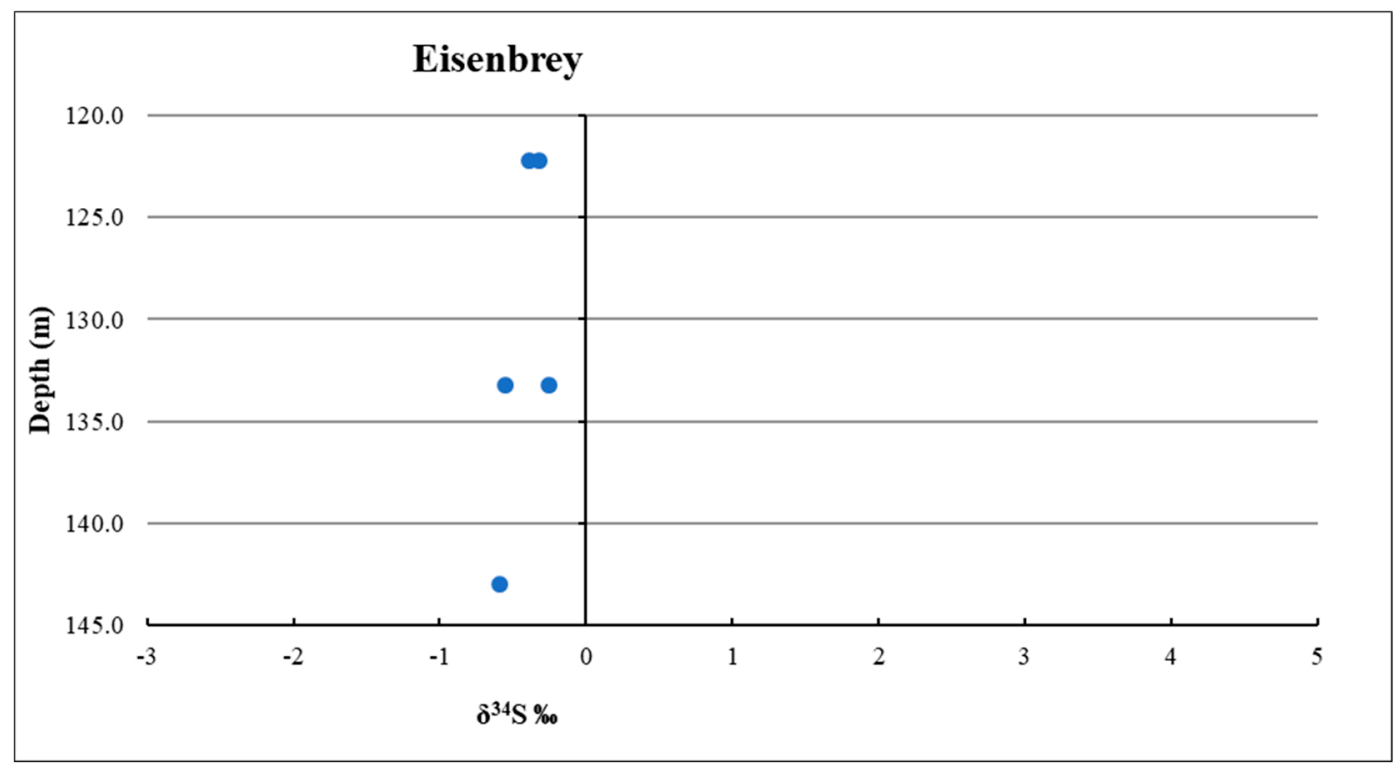

Figure A12. $\delta^{34} \mathrm{~S}$ vs. depth for Eisenbrey deposit.

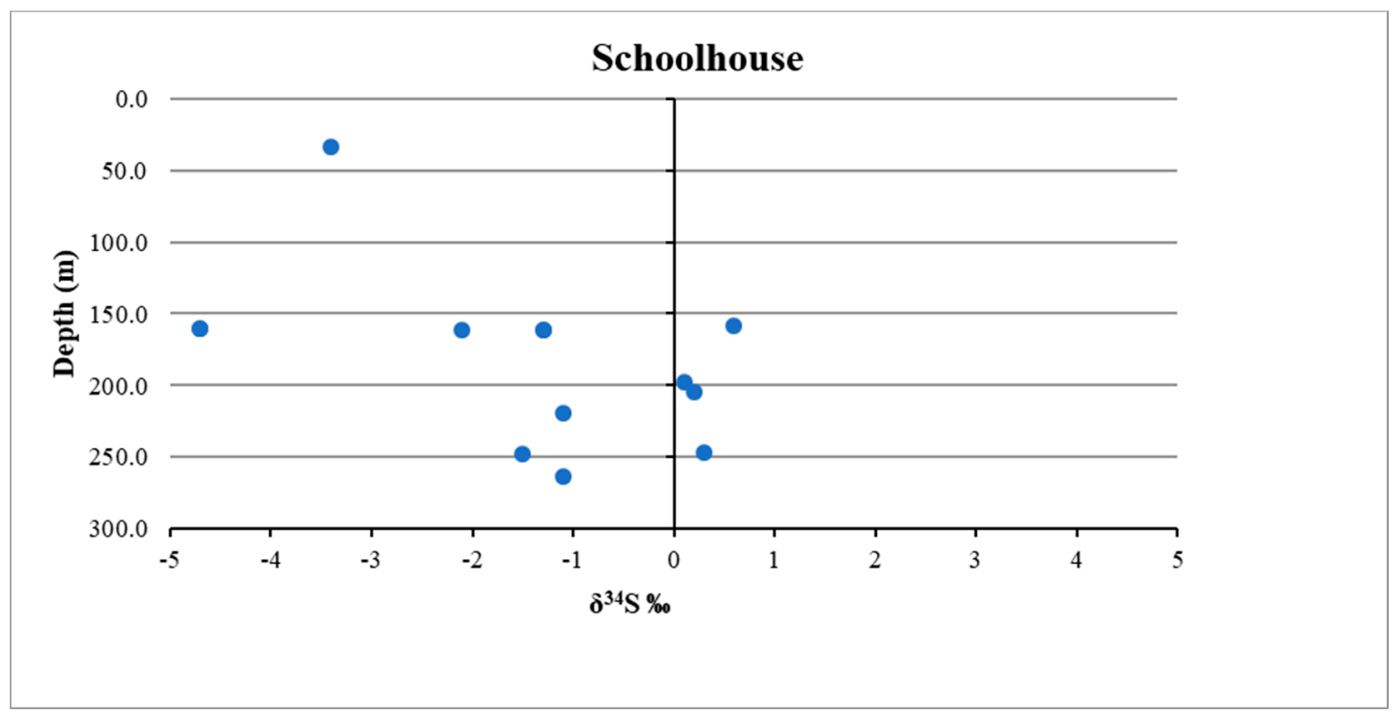

Figure A13. $\delta^{34} \mathrm{~S}$ vs. depth for Schoolhouse deposit. 


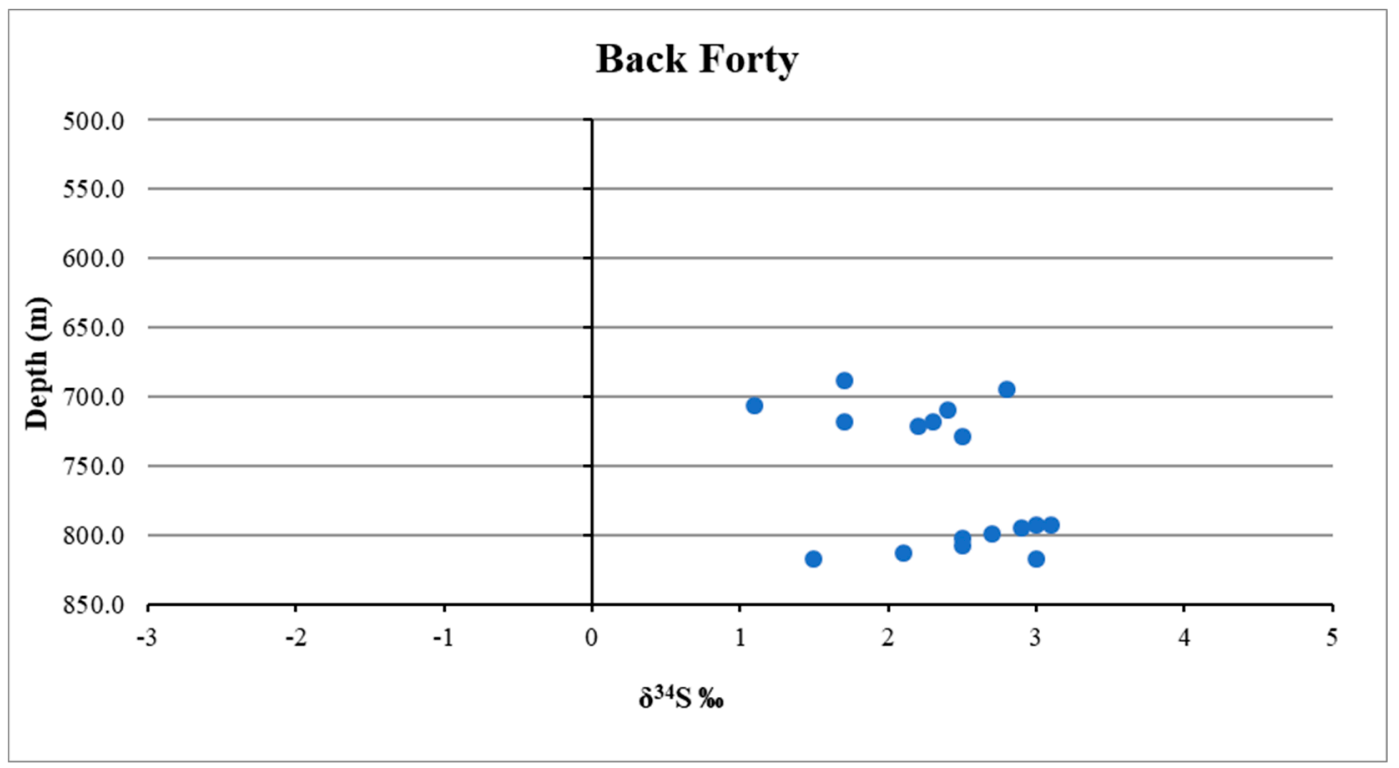

Figure A14. $\delta^{34} \mathrm{~S}$ vs. depth for Back Forty deposit.

\section{References}

1. Franklin, J.M.; Lydon, J.W.; Sangster, D.M. Volcanic-associated massive sulfide deposits. Econ. Geol. 1981, 75, 485-627.

2. Large, R.R. Australian volcanic-hosted massive sulfide deposits; Features, styles, and genetic models. Econ. Geol. 1992, 87, 471-510. [CrossRef]

3. Franklin, J.M.; Gibson, H.L.; Jonasson, I.R.; Galley, A.G. Volcanogenic massive sulfide deposits. Econ. Geol. 2005, 100, 523-560.

4. Galley, A.G.; Hannington, M.D.; Jonasson, I.R. Volcanogenic massive sulphide deposits. Geol. Assoc. Can. Miner. Depos. Div. Spec. Publ. 2007, 5, 141-161.

5. Barrie, C.T.; Hannington, M.D. Classification of volcanic-associated massive sulfide deposit based on host-rock composition. Rev. Econ. Geol. 1999, 8, 1-11.

6. Large, R.R.; McPhie, J.; Gemmell, J.B.; Herrmann, W.; Davidson, G.J. The Spectrum of Ore Deposit Types, Volcanic Environments, Alteration Halos, and Related Exploration Vectors in Submarine Volcanic Successions: Some Examples from Australia. Econ. Geol. 2001, 96, 913-938. [CrossRef]

7. Hannington, M.; Ronde, C.; Peterson, S. Sea-floor tectonics and submarine hydrothermal systems. Econ. Geol. 2005, 100, 111-141.

8. Shanks, W.C. Stable isotopes in seafloor hydrothermal systems: Vent fluids, hydrothermal deposits, hydrothermal alteration, and microbial processes. Rev. Mineral. Geochem. 2001, 43, 469-517. [CrossRef]

9. Huston, D.L. Stable isotopes and their significance for understanding the genesis of volcanic-hosted massive sulfide deposits: A review. Rev. Econ. Geol. 1999, 8, 157-176.

10. Huston, D.L.; Pehrsson, S.; Eglington, B.M.; Zaw, K. The geology and metallogeny of volcanic-hosted massive sulfide deposits: Variations through geologic time and with tectonic setting. Econ. Geol. 2010, 105, 571-591. [CrossRef]

11. Seal, R.R. Sulfur Isotope Geochemistry of Sulfide Minerals. Rev. Mineral. Geochem. 2006, 61, $633-677$. [CrossRef]

12. Ohmoto, H.; Rye, R.O. Isotopes of sulfur and carbon. In Geochemistry of Hydrothermal Ore Deposits, 2nd ed.; Barnes, H.L., Ed.; John Wiley and Sons: New York, NY, USA, 1979; pp. 509-567.

13. Ohmoto, H. Formation of volcanogenic massive sulfide deposits: The Kuroko perspective. Ore Geol. Rev. 1996, 10, 135-177. [CrossRef]

14. Jamieson, J.W.; Wing, B.A.; Hannington, M.D.; Farquhar, J. Evaluating isotopic equilibrium among sulfide mineral pairs in Archean ore deposits: A case study from the Kidd Creek VMS deposit, Ontario, Canada. Econ. Geol. 2006, 101, 1055-1061. [CrossRef] 
15. Sharpe, R.; Gemmell, J.B. Sulfur isotope characteristics of the Archean Cu-Zn Gossan Hill VHMS deposit, Western Australia. Miner. Depos. 2000, 35, 553-550. [CrossRef]

16. Wagner, T.; Boyce, A.J.; Jonsson, E.; Fallick, A.E. Laser microprobe sulphur isotope analysis of arsenopyrite: Experimental calibration and application to the Boliden $\mathrm{Au}-\mathrm{Cu}-\mathrm{As}$ massive sulphide deposit. Ore Geol. Rev. 2004, 25, 311-325. [CrossRef]

17. Bailie, R.; Gutzmer, J.; Strauss, H.; Stüeken, E.; McClung, C. Sulfur isotope characteristics of metamorphosed $\mathrm{Zn}-\mathrm{Cu}$ volcanogenic massive sulfides in the Areachap Group, Northern Cape Province, South Africa. Miner. Depos. 2010, 45, 481-496. [CrossRef]

18. Chen, M.; Campbell, I.; Xue, Y.; Tian, W.; Ireland, T.R.; Holden, P.; Cas, R.; Hayman, P.C.; Das, R. Multiple Sulfur Isotope Analyses Support a Magmatic Model for the Volcanogenic Massive Sulfide Deposits of the Teutonic Bore Volcanic Complex, Yilgarn Craton, Western Australia. Econ. Geol. 2015, 110, 1411-1423. [CrossRef]

19. Vearncombe, S.E. Volcanogenic Massive Sulphide-Sulphate Mineralisation at Strelley, Pilbara Craton, Western Australia. Ph.D. Thesis, University of Western Australia, Perth, Australia, 1995.

20. Ametrano, S.; Etcheverry, R.; Echeveste, H.; Godeas, M.; Zubia, M. VMS district of Tierra del Fuego, Argentina. Geol. Assoc. Can. Mineral Depos. Div. Spec. Publ. 2000, 2, 593-612.

21. Lambert, I.B. Sulphur-isotope investigations of Archaean mineralization and some implications concerning geobiochemical evolution. In Archean Cherty Metasediments: Their Sedimentology, Micropaleontology, Biogeochemistry and Significance to Mineralization; Glover, J.E., Groves, D.I., Eds.; University of Western Australia: Perth, Australia, 1978; pp. 45-56.

22. Bowins, R.J.; Crocket, J.H. Sulfur and carbon isotopes in Archean banded iron formations: Implications for sulfur sources. Chem. Geol. 1994, 111, 307-323. [CrossRef]

23. Myers, L.L. Geochemistry of the Crandon Massive Sulfide Deposit, Wisconsin: Sulfur Isotope and Fluid Inclusion Data. Bachelor's Thesis, University of Wisconsin-Madison, Madison, WI, USA, 1983.

24. Schulz, K.J.; Cannon, W.F. The Penokean Orogeny in the Lake Superior Region. Precambrian Res. 2007, 157, 4-25. [CrossRef]

25. DeMatties, T.A. Early Proterozoic volcanogenic massive sulfide deposits in Wisconsin: An overview. Econ. Geol. 1994, 89, 1122-1151. [CrossRef]

26. LaBerge, G.L. General characteristics and geologic setting of the Wisconsin magmatic terranes. In olcanogenic Massive Sulfide Deposits of Northern Wisconsin: A Commemorative Volume; Institute on Lake Superior Geology: St Paul, MN, USA, 1996; pp. 17-30.

27. Schulz, K.J.; Nicholson, S.W.; Van Schmus, W.R. Penokean massive sulfide deposits: Age, geochemistry, and paleotectonic setting. In Proceedings of the 54th Annual Meeting of the Institute on Lake Superior Geology, Marquette, MI, USA, 6-10 May 2008.

28. Quigley, P.O. The Spectrum of Ore Deposit Types, Their Alteration and Volcanic Setting in the Penokean Volcanic Belt, Great Lakes Region, USA. MS Thesis, Colorado School of Mines, Golden, CO, USA, 2016.

29. Boxleiter, A.; Thakurta, J.; Quigley, T. Geochemical investigation of the origin of the Back Forty volcanogenic massive sulfide deposit in Menominee County, MI. In Proceedings of the 60th Annual Institute on Lake Superior Geology Conference, Hibbing, MN, USA, 14-17 May 2014; pp. 17-18.

30. DeMatties, T.A. A proposed geologic framework for massive sulfide deposits in the Wisconsin Penokean volcanic belt. Econ. Geol. 1989, 84, 946-952. [CrossRef]

31. Sims, P.K. Geologic map of Precambrian rocks, Southern Lake Superior Region, Wisconsin and Northern Michigan. In U.S. Geological Survey Miscellaneous Investigation Series Map I-2185; USGS Publication: Reston, VA, USA, 1992.

32. Sims, P.K.; Carter, L.M.H. Archean and Proterozoic Geology of the Lake Superior Region, U.S.A., 1993; USGS Publication: Reston, VA, USA, 1996.

33. DeMatties, T.A.; Rowell, W.F. The Bend deposit. In Volcanogenic Massive Sulfide Deposits of Northern Wisconsin: A Commemorative Volume; Institute on Lake Superior Geology: St Paul, MN, USA, 1996; pp. 143-159.

34. Quigley, A.K. Setting of Volcanogenic Massive Sulfide Deposits in the Penokean Volcanic Belt, Great Lakes Region, USA. MS Thesis, Colorado School of Mines, Golden, CO, USA, 2016.

35. DeMatties, T.A. On Paleoproterozoic volcanogenic massive sulfide (VMS) mineralization in the Penokean volcanic belt, northen Wisconsin and eastern Michigan, USA: Implications for future exploration. Ore Geol. Rev. 2018, 95, 216-237. [CrossRef] 
36. Woodruff, L.; (United States Geological Survey, Reston, VA, USA). Personal communication. 2014.

37. Piercy, S.J. The setting, style, and role of magmatism in the formation of volcanogenic massive sulfide deposits. Miner. Depos. 2011, 46, 449-471. [CrossRef]

38. Thakurta, J.; Quigley, T. Geochemical characterization of the Back Forty volcanogenic massive sulfide deposit in Menominee County, Michigan. Geol. Soc. Am. Abstr. Programs 2013, 45, 806.

39. Zens, Z.; Helmuth, S.; Lodge, R.W. Geochemistry and petrography of the strata hosting the Flambeau $\mathrm{Cu}-\mathrm{Zn}-\mathrm{Au}$ deposit; Revisiting Wisconsin's only past-producing volcanogenic massive sulfide mine. Geol. Soc. Am. Abstr. Programs 2015, 47, 28.

40. Thode, H.G.; Monster, J.; Dunford, H.B. Sulphur isotope geochemistry. Geochim. Cosmochim. Acta 1961, 25, 159-174. [CrossRef]

41. Ripley, E.M.; Li, C. Sulfur isotope exchange and metal enrichment in the formation of magmatic Cu-Ni-(PGE) deposits. Econ. Geol. 2003, 98, 365-641. [CrossRef]

42. Sakai, H.; DesMarais, D.J.; Ueda, A.; Moore, J.G. Concentrations and isotope ratios of carbon, nitrogen, and sulfur in ocean-floor basalts. Geochim. Cosmochim. Acta 1984, 48, 2430-2441. [CrossRef]

43. Rees, C.E.; Jenkins, W.J.; Monster, J. The sulfur isotopic composition of ocean water sulfate. Geochim. Cosmochim. Acta 1978, 42, 377-381. [CrossRef]

44. Claypool, G.E.; Holser, W.T.; Kaplan, I.R.; Sakai, H.; Zak, I. The age curves of sulfur and oxygen isotopes in marine sulfate and their mutual interpretation. Chem. Geol. 1980, 28, 199-260. [CrossRef]

45. Chambers, L.A.; Trudinger, P.A. Microbiological fractionation of stable sulfur isotopes: A review and critique. Geomicrobiol. J. 1979, 1, 249-293. [CrossRef]

46. Seal, R.R.; Wandless, G.A. Sulfur isotope evidence for sea-floor mineralizing processes at the Bald Mountain and Mount Chase massive sulfide deposits, northern Maine. Econ. Geol. Monogr. 2003, 11, 567-587.

47. Sims, P.K.; Van Schmus, W.R.; Schulz, K.J.; Peterman, Z.E. Tectono-stratigraphic evolution of the Early Proterozoic Wisconsin magmatic terranes of the Penokean orogen. Can. J. Earth Sci. 1989, 25, 2145-2158. [CrossRef]

48. Canfield, D.E.; Teske, A. Late Proterozoic rise in atmospheric oxygen concentration inferred from phylogenetic and sulphur-isotope studies. Nature 1996, 382, 127-132. [CrossRef] [PubMed]

49. Gellatly, A.M.; Lyons, T.W. Trace sulfate in mid-Proterozoic carbonates and the sulfur isotope record of biospheric evolution. Geochim. Cosmochim. Acta 2005, 69, 3813-3829. [CrossRef]

50. Slack, J.F.; Grenne, T.; Bekker, A.; Rouxel, O.J.; Lindberg, P.A. Suboxic deep seawater in the late Paleoproterozoic: Evidence from hematitic chert and iron formation related to seafloor-hydrothermal sulfide deposits, central Arizona, USA. Earth Planet. Sci. Lett. 2007, 255, 243-256. [CrossRef] 